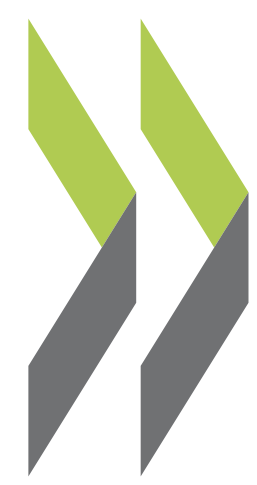

OECD Economics Department Working Papers No. 1082

The Benefits and Costs of Highly Expansionary Monetary Policy

\section{kukasz Rawdanowicz,}

Romain Bouis, Shingo Watanabe 


\section{Unclassified}

ECO/WKP(2013)74

Organisation de Coopération et de Développement Économiques

Organisation for Economic Co-operation and Development

12-Aug-2013

ECONOMICS DEPARTMENT

English - Or. English

THE BENEFITS AND COSTS OF HIGHLY EXPANSIONARY MONETARY POLICY

ECONOMICS DEPARTMENT WORKING PAPER No. 1082

By Lukasz Rawdanowicz, Romain Bouis and Shingo Watanabe

All Economics Department Working Papers are available through OECD's Internet website at http://www.oecd.org/eco/Workingpapers

JT03343556

Complete document available on OLIS in its original format

This document and any map included herein are without prejudice to the status of or sovereignty over any territory, to the delimitation of international frontiers and boundaries and to the name of any territory, city or area. 


\section{ABSTRACT/RÉSUMÉ}

\section{The benefits and costs of highly expansionary monetary policy}

How far to go - and to remain - in the direction of highly expansionary monetary policy hinges on the balance of marginal benefits and costs of additional monetary easing and its expected evolution over time. This paper sketches a framework for assessing this balance and applies it to four OECD economic areas: the euro area, Japan, the United Kingdom and the United States. The effectiveness of further stimulus via quantitative easing or forward guidance in affecting asset prices, interest rates and credit flows will depend on the state of the economy and the functioning of financial markets. Marginal costs could rise due to excessive risk-taking; higher inflation expectations; higher likelihood of ever-greening; and higher risks of financial instability in the exit phase, especially when exit from monetary accommodation is close in time and signs of negative effects are already apparent. The balance of marginal benefits and costs is found to be different across the main OECD areas. In the United States, the case for additional stimulus is weakening, while the opposite is true for the euro area and Japan. In the United Kingdom, the assessment is less clear cut.

JEL classification codes: E31; E43; E44; E5; F31; F32; G12; G21

Keywords: Monetary policy, quantitative easing, forward guidance, asset price booms, ever-greening, spillovers

$* * * * * * * * * * * * * * * * * * * * * *$

\section{Les avantages et coûts d'une politique monétaire très expansionniste}

Jusqu'où aller - et demeurer - dans la direction d'une politique monétaire hautement expansionniste dépend du solde entre les avantages et coûts de l'assouplissement monétaire additionnel et de son évolution attendue dans le temps. Ce document propose une ébauche d'un cadre d'analyse pour évaluer ce solde et l'applique à quatre principales régions économiques de l'OCDE : les États-Unis, la zone euro, le Japon et le Royaume-Uni. L'efficacité d'un stimulus additionnel via l'assouplissement quantitatif ou des indications prospectives pour affecter les prix d'actifs, les taux d'intérêt et les flux de crédit dépendra de l'état de l'économie et du fonctionnement des marchés financiers. Les coûts marginaux pourraient croître en raison d'une prise de risques excessive ; d'anticipations d'inflation plus élevées ; d'une plus grande probabilité de régénération des créances douteuses ; et de risques accrus d'instabilité financière dans la phase de sortie, surtout lorsque la sortie de la politique monétaire accommodante est proche dans le temps et que les signes d'effets négatifs sont déjà apparents. Le solde entre les avantages et coûts est estimé être différent au sein des principales régions de l'OCDE. Aux États-Unis, l'argument en faveur d'un stimulus additionnel s'est affaibli, tandis que l'opposé est vrai pour la zone euro et le Japon. Au Royaume-Uni, le diagnostic est moins clair.

Codes JEL : E31 ; E43 ; E44 ; E5 ; F31 ; F32 ; G12 ; G21

Mots clé : politique monétaire, assouplissement quantitatif, indications prospectives, boom de prix d'actifs, régénération, retombées 


\section{TABLE OF CONTENTS}

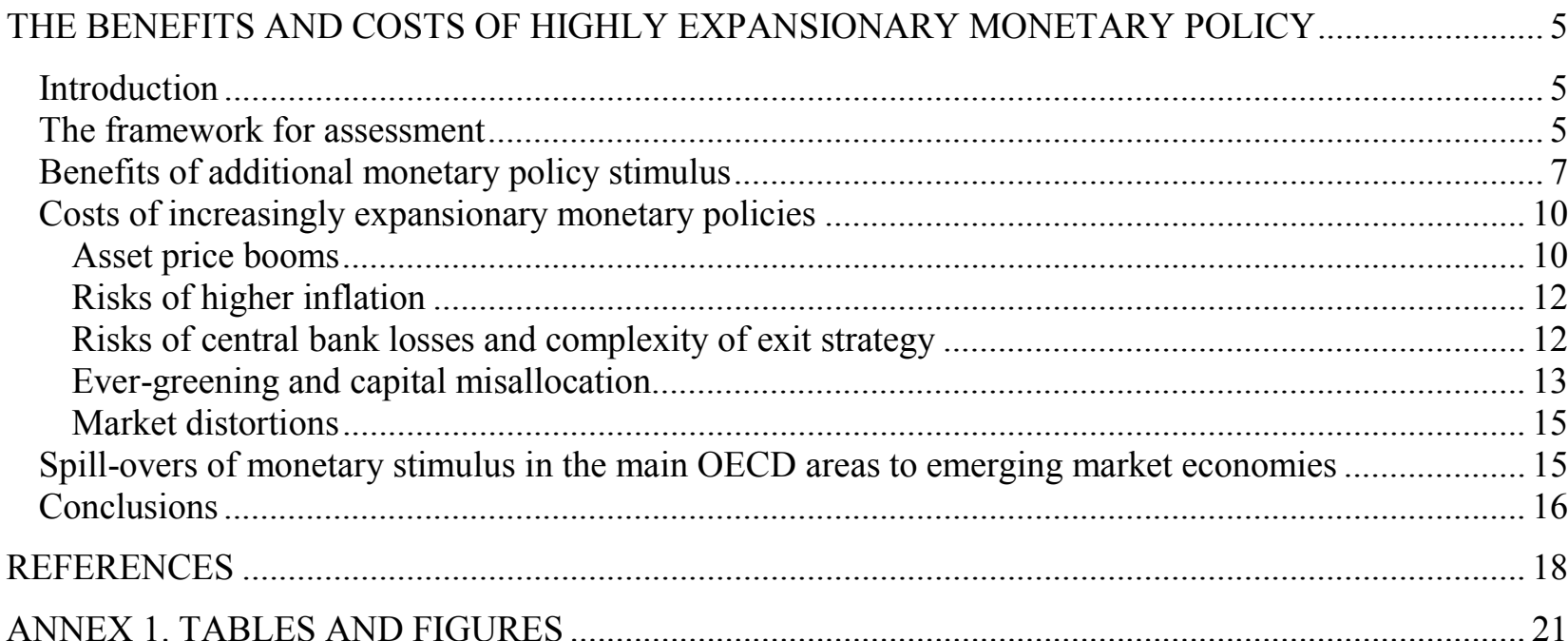

\section{Tables}

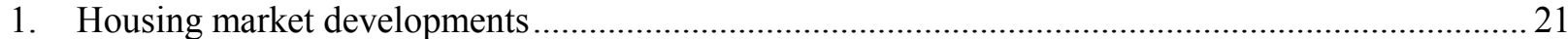

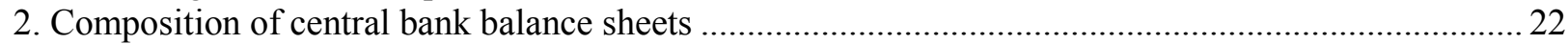

3. Framework of assessing benefits and costs of additional monetary stimulus ..................................... 23

\section{Figures}

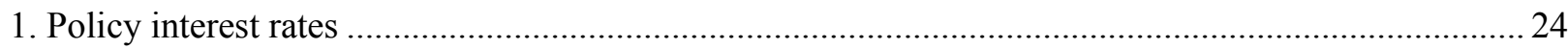

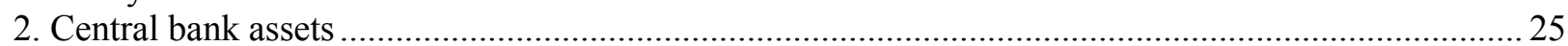

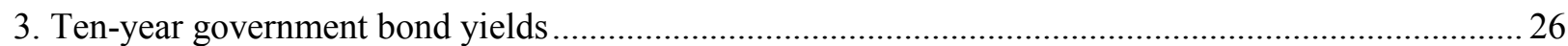

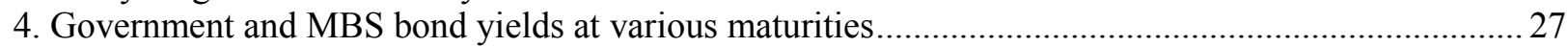

5. Changes in bond yields on the announcement of asset purchases.................................................. 28

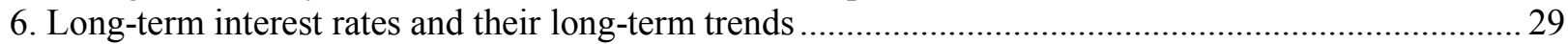

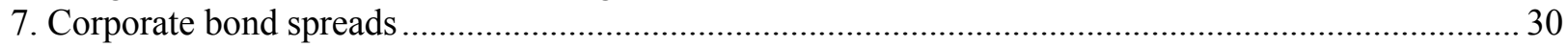

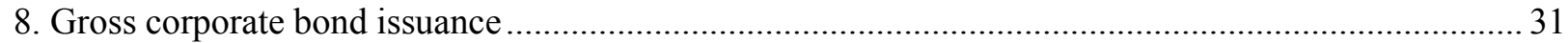

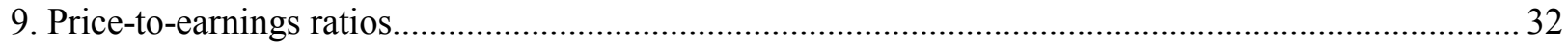

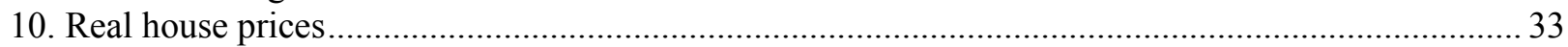

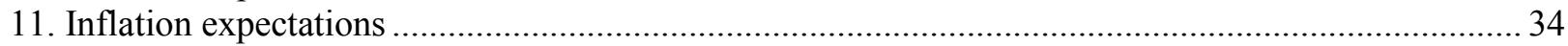

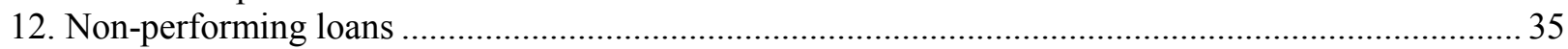

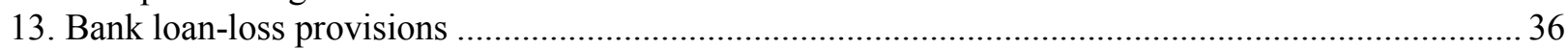

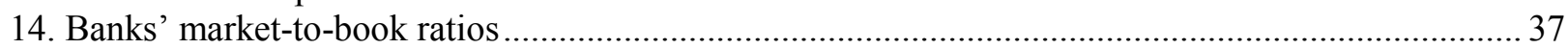

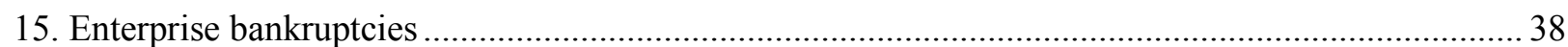

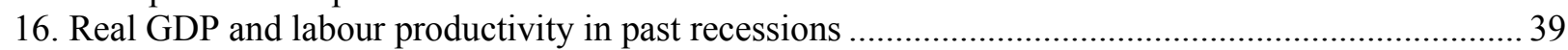

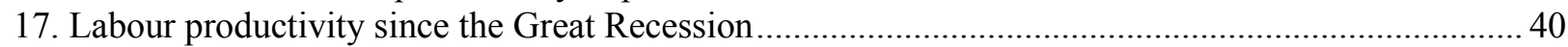

18. Nominal effective exchange rates since the onset of the Great Recession........................................ 41 
ECO/WKP(2013)74

\section{Boxes}

Box 1. Effectiveness of central banks' forward guidance policies ...................................................... 9

Box 2. Ever-greening in Japan in the 1990s.................................................................................. 14 
ECO/WKP(2013)74

\title{
THE BENEFITS AND COSTS OF HIGHLY EXPANSIONARY MONETARY POLICY
}

\author{
By \\ Łukasz Rawdanowicz, Romain Bouis and Shingo Watanabe ${ }^{1}$
}

\section{Introduction}

Five years after the Great Recession, the monetary policy stance is highly expansionary in the main OECD economies and becoming more so in some. How far to go - and to remain - in the direction of expansion hinges on the balance of marginal benefits and costs of additional monetary easing and its expected evolution over time. This paper sketches a framework for assessing benefits and costs of additional easing and applies it to analyse separately benefits and costs, with issues related to international spill-overs to emerging markets discussed at the end.

\section{The framework for assessment}

With policy interest rates close to zero in main OECD economies, additional stimulus has relied mainly on affecting long-term interest rates via quantitative easing $(\mathrm{QE})$ or forward guidance. The framework below identifies the main benefits and costs associated with additional monetary policy easing, and how the individual components can vary over time depending on the state of the economy and the functioning of financial markets. It highlights the risk that marginal benefits may fall below marginal costs at some point.

The degree of stimulus from asset purchases depends on the extent of the fall in yields on these assets and the ripple effects that this has through the rebalancing of portfolios. The impact varies in strength depending on the state of financial markets: starting from depressed panic-driven asset prices, purchases should have stronger effects on yields of the asset being bought than if the same amount of buying takes place in a richly valued market and yields in bond markets are ultimately constrained by the (near-)zero lower bound on short rates. Hence, QE may be particularly effective during crises in driving asset prices up but then its marginal returns could diminish over time as asset valuations increase.

The degree of stimulus from forward guidance on future accommodative monetary policy will also depend on its impact on bond yields and other asset prices. The effectiveness hinges on the credibility of the commitment to maintain a more accommodative stance in the future than markets would expect in the absence of guidance and the public's understanding of the central bank's intentions. Provided that it is seen to convey credible information and that markets subscribe to the intended future policy stance, forward guidance should be effective in driving down yields. However, extending forward guidance further and further into the future as a means of providing additional stimulus may be less credible and hence ineffective.

By maintaining low interest rates monetary policy can bring demand forward but its effectiveness will tend to decline over time if expectations of future income do not increase. Moreover, in the current environment, the effectiveness of lower cost of credit in stimulating private consumption and investment

1. The authors are members of the Macroeconomic Policy Division of the Economics Department. They are indebted to Ane Kathrine Christensen and Catherine Lemoine for statistical help and to Sveinbjörn Blöndal, Jørgen Elmeskov, Peter Jarrett, Paul O’Brien, and Jean-Luc Schneider for their useful comments. The authors are also grateful to Maartje Michelson for help in the final document preparation. The opinions expressed in this paper are those of the authors and are not necessarily shared by the OECD or its member countries. 
will hinge on the functioning of the bank lending channel. Marginal benefits of extra stimulus will be larger when banks are ready to increase the availability of credit through adjustments in credit standards in response to easier monetary conditions than if credit standards remain tight.

The potential benefits of extra monetary easing will also depend on the state of the economy. They are particularly large for an economy in, or at risk of, deflation or recession, given the high costs involved with falling price and activity levels. Thus, even if there remain doubts about its effectiveness, extra stimulus is likely warranted in such situations. The opposite holds if the economy is growing at potential and inflation is not far from targets. However, even in the latter case, the benefits may justify additional asset purchases if unemployment and economic slack are high.

The potential costs of additional monetary easing can take various forms:

- Risk-taking can become excessive whereby some asset prices are bid up to too elevated levels, risking financial instability in the future. Continued asset purchases or forward guidance when investors have become very tolerant to risk could result in excesses, while asset purchases and forward guidance in depressed markets are unlikely to have such effects.

- Inflation expectations can rise above targets, with the risk of additional monetary stimulus having such effects depending on the starting point. It is more likely to unsettle inflation expectations if expectations are already above targets or the stock of purchased assets is high, raising concerns about the ability and willingness of the central bank to unwind stimulus in a timely manner and thus control inflation.

- Additional asset purchases when holdings are already high add to future exit challenges, notably the risk of bond market instability in the exit phase. The current discounted costs of such possible future events depend on the time to, and the expected pace of, normalisation of monetary policy. Thus, the current costs will be higher if the start of exit is relatively close in time and if there are risks of abrupt policy reversal than if it is likely to take place far into the future and policy tightening can occur gradually.

- Risks to central bank independence may emerge in the exit phase when losses are likely on its asset holdings as interest rates normalise. The cost in terms of lower credibility may be higher at the margin when asset holdings are high and losses threaten to wipe out the capital of the central bank.

- The ever-greening of de facto non-performing loans, encouraged by low interest rates, undermines creative destruction and productivity gains in the economy. If evidence, such as high recorded non-performing loans and bankruptcies, suggests little incidence of ever-greening in an economy, additional monetary easing may run a lower risk of resulting in such practices than if ever-greening practices appear to be widespread.

- Adding to an already large stock of assets would lead to increased dominance by the central bank in the market segments where purchases take place and could involve less liquid markets and other efficiency losses. This would be less of a concern when central bank's asset holdings are low.

Global benefits and costs at the margin may differ from those of an individual country easing monetary policy because of spill-overs. For foreign countries, the spill-overs can involve benefits, such as additional foreign demand and increased availability of foreign finance, and costs, including currency appreciation and destabilising capital inflows and subsequent outflows. The extent of these benefits and costs will depend importantly on domestic policy setting in foreign countries, and in particular emerging 
market economies, including the degree of exchange rate flexibility and the stance of macroeconomic and macro-prudential policies. However, with the net benefits of monetary easing in one country on the rest of the world being related to policies at the discretion of other countries, it is not obvious that decisions about relaxing monetary policy in one country should attempt to take into account international impacts, as long as they remain moderate and manageable.

\section{Benefits of additional monetary policy stimulus}

Over the past five years, the monetary policy stance in many OECD countries has been extraordinarily expansionary. Following cuts in key policy rates to nearly zero in several countries, between late 2007 and early 2009, they have been maintained at this level for four years (Figure 1$)^{2}-\mathrm{a}$ development not seen over the past century. In addition, a number of non-conventional measures have been implemented, involving, in particular, the expansion of monetary authorities' balance sheets, which have at least doubled in many areas (Figure 2). Other unconventional measures included forward guidance in Canada, Japan, and the United States; in the case of the United States conditional commitment to maintain low interest rates shifted from being calendar based to being linked to economic conditions (Box 1). Also, the Swiss central bank intervened in the currency market to limit franc appreciation, resulting in the quadrupling of the central bank's total assets. The highly expansionary monetary policy stance contributed to initially preventing total financial meltdown and deflation and subsequently, and with a varying success, supporting economic growth over recent years (Bouis et al., 2013).

The conjecture discussed above that the effectiveness of additional stimulus is likely to fall when asset prices are already elevated is consistent with evidence on the past asset purchase programmes in the United Kingdom and the United States. The first QE programmes reduced substantially government bond yields, even if the duration of this effect is controversial, whereas subsequent programmes have had much less effect (Marin and Milas, 2012). Thus, event studies indicate that QE1 in the United States reduced 10-year government bond yields by around 100 basis points, or just below 10 basis points per $\$ 100$ billion of announced asset purchases, while the yield reduction per $\$ 100$ billion of announced purchases in the QE2 programme is estimated to have been at most only 5 basis points. In the United Kingdom, while the first asset buying programme is estimated to have reduced yields by 100 basis points, similar event studies fail to detect any yield cuts associated with the second bond buying programme (Goodhart and Ashworth, 2012).

Changes in asset prices following the implementation of the most recent QE programmes give mixed signals concerning their potential effectiveness ${ }^{3}$ and imply differentiated scope for increasing them further in the future (Figures 3-5):

- In the United States, 10-year government bond yields did not fall on the announcement of continued purchases of Treasuries after the termination of "Operation Twist" at the end of 2012, and went slightly up until mid-March, possibly reflecting other factors such as increased confidence in the state of the US economy. In contrast, on the announcement of the purchase of \$40 billion MBS per month in September 2012 the yields on MBS declined but soon after they went up, rising almost uninterruptedly until end-May 2013 and interest rates on mortgages followed suit though with some delay. In contrast, equity prices significantly rose between September 2012 and mid-May 2013.

2. In Canada, the euro area and Sweden some of the initial stimulus was withdrawn in 2010-11, but in the euro area and Sweden policy rates were cut anew in the second half of 2011 and in 2012.

3. Analysing behaviour of asset prices following a policy change may confound the effects of a policy measure with a multitude of other factors and does not provide information on what would have happened in the absence of the policy measure. Thus, it may not be a proof of policy effectiveness. 
- In Japan, announcements during 2012 and early 2013 that the Bank of Japan would purchase additional bills and bonds moved mostly downwards 10-year government bond yields on the days of announcements, contributing to a cumulative drop in yields by around 50 basis points between the beginning of 2012 and end-March 2013. Besides impacts on long-term interest rates, expectations of easier future monetary policy also helped push down the value of the yen and raise equity prices between November 2012 and May 2013, which, if sustained, should give a strong boost to growth.

- In the United Kingdom, following the latest decision to expand quantitative easing in July 2012, 10 -year bond yields declined on impact but they went up by around 80 basis points between July 2012 and February 2013. Nevertheless, equity increased and the pound sterling depreciated between November 2012 and May 2013.

In the United Kingdom and the United States, at the current levels of long-term government and corporate bonds yields at or above $2 \%$, there is still, in principle, scope for lowering them further by additional monetary policy stimulus. In Japan, the scope is more limited, but if moderate inflation were to be achieved, current positive real interest rates could become negative and thus more stimulative.

Forward guidance in the United States and Canada since the onset of the crisis has typically had the intended effect of lowering expected future policy rates and hence bond yields (Box 1). Thus, the announcement by the Bank of Canada containing the conditional forward guidance in November 2009 had instantaneous effects on market expectations. Also, forward guidance statements of the Federal Reserve aimed at easing policy led to a lower expected path for the federal funds rate (Campbell et al., 2012; Woodford, 2012). In the case of the Federal Reserve, the shift from forward guidance based on calendar dates to economic conditions in December 2012 did not result in any drop in market rates as this was not intended or interpreted as easing the stance of policy. Overall, forward guidance has been effective since 2008 .

After having limited the impact of past monetary accommodation on growth in the early stages of the crisis, banking systems appear now to be working more efficiently in many economies and this should make asset purchases and forward guidance more effective in stimulating demand. Monetary easing in the past took place against the background of banks tightening their lending standards and limiting credit availability as they repaired their balance sheets. This contributed to weak credit developments even with a significant reduction in the cost of credit. However, the recent easing of credit conditions in Japan, the United Kingdom and the United States suggests that the bank credit channel is becoming more effective. Indeed, in Japan and the United States, credit to the private sector has been increasing since around the middle of 2011. In contrast, credit conditions remain tight in the euro area, especially in vulnerable member states.

Potential benefits of more stimulus are larger in countries with weak growth, increasing negative output gaps and strong disinflationary pressures. Given renewed recession and growing disinflationary pressures in the euro area, reflecting the dire situation of vulnerable countries, additional monetary easing would be warranted. The same applies to Japan, where deflation persists, inflation is projected to substantially undershoot the target in 2013 and fiscal headwinds will restrain growth in coming years. The assessment for the United Kingdom is less clear cut: weak growth and the expected slow narrowing of the negative output gap call for more stimulus, whereas the persistent continued overshooting of the inflation target points in the opposite direction. On the other hand, in the United States, with growth not far from potential, and expected to strengthen and unemployment set to continue to decline in the near term, the case for additional stimulus is weakening, notwithstanding large estimated economic slack. 


\section{Box 1. Effectiveness of central banks' forward guidance policies}

Forward guidance signals the likely future path of interest rates (or in fact of any other policy measure). Since the effects of monetary policy depend on both current and expected future policy settings, announcing a future path could affect market expectations and increase policy effectiveness. Forward guidance could be particularly useful when interest rates are at the zero lower bound as discussed by Yellen (2012) and Carney (2012). This box describes different forms of forward guidance and discusses its effectiveness in the current environment.

Forward guidance can take various forms. The most explicit is a regular publication of a forecast of future interest rates along macro projections to facilitate understanding of the policy reaction function by financial markets, as it is done in the Czech Republic, Iceland, New Zealand, Norway and Sweden (Svensson, 2009). On the other extreme, central banks can use, sporadically, "code words" to indicate the likely direction of future changes in policy rates, as was practiced by some central banks in the past.

Forward guidance has also been used to address constraints implied by the lower bound of the policy rate. The first use of forward guidance in such a context was by the Bank of Japan (BoJ) in April 1999, when it committed to maintain the zero policy rate until deflationary concerns were dispelled. This continued until August 2000. The BoJ renewed forward guidance policy in October 2010 and now commits to maintain the quantitative and qualitative easing until $2 \%$ inflation is attained. The US Federal Reserve (Fed) used the forward guidance policy in the second half of 2003 , when interest rates were lowered to $1 \%$, by explicitly committing to not raising policy rates for an extended period. Between December 2008 and November 2012 the Fed made a series of similar announcements, making a conditional commitment to maintain the very low policy rate for a period of time and recently stating that a highly accommodative policy stance was expected to remain appropriate for a considerable time after the recovery strengthens. In December 2012, forward guidance was changed by explicitly linking the duration of the exceptionally low policy rate with the conditions that the unemployment rate remains above $6.5 \%$, inflation between one and two years ahead is projected to be no more than $2.5 \%$, and longer-term inflation expectations continue to be well anchored. The Bank of Canada stated in April 2009 that it would keep the policy interest rate low until the end of the second quarter of 2010 (in practice the rate was raised in April 2010). The Fed has applied forward guidance to its quantitative easing measures by committing to continue purchasing mortgage-backed securities until the outlook for the labour market improves substantially; in June 2013, it announced that purchases would remain in place until the unemployment rate falls to $7 \%$.

The effectiveness of forward guidance policy in the presence of zero lower interest rate bound depends on how market expectations respond to central bank announcements. If market participants perceive that there are few costs for central banks from reneging on their commitments or expect that the very accommodative policy would continue for only a relatively short period of time, it is difficult to make forward guidance fully credible and powerful policy. One way to strengthen the effectiveness of policy announcements is to use precise economic conditions rather than vague conditions or calendar dates for maintaining monetary stimulus in the future, because the former can be more easily interpreted and predicted by financial markets and because market expectations can adjust to changing economic conditions. As discussed above, so far only the Federal Reserve has started to give very clear economic conditions for the maintenance of current low interest rates. The effectiveness and credibility of forward guidance can be further enhanced by changing the policy framework to price or nominal GDP level targeting which allows a central bank to credibly commit to keeping interest rates low for longer even with inflation staying above the long-term target, or by combining it with large-scale asset purchase programmes, because a central bank can send a signal about future policy rates that it regards desirable by influencing long-term rates (Eggertsson and Woodford, 2003; Woodford 2012).

The assessment of forward guidance is challenging due to the difficulties of identifying all the different factors that affect market interest rates and the difficulty of designing appropriate counterfactual simulations. For instance, lower interest rates after the announcement of forward guidance may reflect expectations of weaker GDP growth and inflation rather than a belief that policy rates are going to be held at extremely low levels for longer than previously thought. Indeed some studies emphasise that the extent to which forward guidance improves central banks' control over long-term interest rates is weak (Moessner and Nelson, 2008; Anderson and Hoffman, 2010). On the other hand, several event studies find support for the role of forward guidance in lowering short and long-term interest rates in the United States (Bernanke et al., 2004; Williams, 2011; Campbell et al., 2012). Similarly, following the Bank of Canada's announcement in April 2009, market interest rates in Canada were found to be lower than implied by econometric models estimated over the pre-announcement period (He, 2010). 


\section{Costs of increasingly expansionary monetary policies}

\section{Asset price booms}

Asset purchases and forward guidance can fuel asset price booms over time by affecting directly prices of the purchased assets and indirectly prices of other assets via portfolio rebalancing. ${ }^{4}$ Upon the normalisation of monetary policy, some payback is inevitable and at least part of the increase in asset prices will be reversed, with potential negative implications for financial stability and growth in the adjustment period. The expansion of monetary stimulus has thus the potential to increase marginal costs, especially if very high valuations are already apparent. Recent price developments of different asset classes are reviewed below, without an attempt to link them directly to monetary policy measures.

Government bond yields in many OECD countries declined over the past five years to record low levels due to a combination of expectations of lower future policy rates and safe-haven and liquidity effects, ${ }^{5}$ which more than offset any tendency for premia to rise because of public debt accumulation (Figures 3 and 4). While it is hard to characterise the current situation in government bond markets as a bubble, the factors driving down yields will reverse as economies normalise in the future. Even a mere reversal to trend levels for yields (calculated on the basis of growth in nominal potential GDP per capita) would imply an increase of between 2 to 4 percentage points in Germany, the United Kingdom and the United States (Figure 6). ${ }^{6}$ Such a rise in yields would imply losses for bond holders, as bond prices would fall by at least one-fifth, with risks to market stability. In contrast, despite some reduction in sovereign bond yields in vulnerable euro area countries, they remain high, implying less potential for a yield increase in the future if the normalisation of spreads continues.

Asset price booms also became apparent in corporate bond markets. In the first half of 2013 up to mid-May, spreads of high-yield and investment-grade corporate bonds vis-à-vis sovereign bond yields reverted to close to their average levels of 2005-06, when risk is widely judged to have been under-priced (Figure 7). Thus, bonds, especially of low-rated companies, looked increasingly expensive, and the compressed yields arguable did not adequately compensate for risks. Yields fell despite higher supply of bonds. Over the past four years, the gross issuance of corporate bonds by non-financial companies increased in the United States and the United Kingdom but not in the euro area and in Japan, where the total issuance in 2010-12 remained below the 2009 peak (Figure 8). Risks to financial stability of a decline in corporate bond prices or higher defaults would increase if corporate bond purchases are funded by short-

4. Low returns on investment-grade financial assets resulting from monetary policy actions can push asset managers to search for yield, which necessitates accepting higher risk (Rajan, 2005 and 2006). Higher risktaking could also result from moral hazard, with expectations building up that monetary policy would help financial institutions recover from bad investments (Minegishi and Cournède, 2010; Farhi and Tirole, 2012; and Hahm et al., 2012). In addition, low interest rates can boost net interest margins and financial firms' value, leading potentially to higher leverage and more risk-taking (Adrian and Shin, 2009 and 2010).

5. Liquidity effects in the United States show up in a much larger decline in sovereign bond yields than in government agency bond yields (by around 70 basis points) during recent episodes of mounting financial stress. Under such circumstances, investors primarily value liquidity and safety of assets. Sovereign bonds are typically perceived as having both features, whereas government agency bonds benefit only from safety. This contrasts with developments in Canada, France, Germany, Japan and the United Kingdom (Box 2 in Bouis et al., 2013).

6. Trend values are calculated as a sum of growth rates of potential GDP per capita (based on the OECD methodology - see Johansson et al., 2012), long-term inflation expectations (based on Consensus Economics) and a constant term. The trend level is surrounded by uncertainty related to estimates of potential growth. 
term borrowing. ${ }^{7}$ In the United States, short-term funding of corporate bond purchases seems to be relatively low. ${ }^{8}$ However, increasing inflows into mutual funds and exchange-traded funds, which invest in high-yield bonds and the expansion of agency mortgage real estate investment trusts ${ }^{9}$ in recent years give rise to concern (Stein, 2013). The growth of exchange-traded and real estate funds has also been observed in Europe over the past three years (ESMA, 2013).

Equity prices also increased strongly before mid-May 2013, especially in Japan, the United Kingdom and the United States, and to a lesser extent in the euro area. Price-to-earnings (P/E) ratios since 2008 have hovered around or below equilibrium benchmarks based on the 1983-2012 period, suggesting that stock valuation is not excessive (Figure 9). However, they have been above benchmarks based on a longer history. ${ }^{10}$ Further policy stimulus could drive equity prices higher, increasing a risk of a larger stockmarket correction when monetary policy normalises or if returns fall short of expectations.

House price dynamics and valuation in the main OECD countries with highly expansionary monetary policy are mixed (Figure 10 and Table 1). House prices have recently increased in the United States, but property prices do not seem to be high according to long-term averages of price-to-rent and price-toincome ratios, suggesting that further monetary stimulus is unlikely to risk overheating in residential property markets in the near term. Falling and undervalued house prices in Japan have the same implications. Further stimulus in the euro area would not imply an immediate risk of housing market overheating either, though trends in house prices differ markedly among the euro area countries. House prices have been falling in most vulnerable countries, but rising in some core countries (especially in Austria and Germany) though largely from low levels. ${ }^{11}$ In the United Kingdom, recent house price increases have taken place against the background of price-to-rent and price-to-income ratios still above the long-term trends (though lower than at the recent peak).

The overview above suggest that there could be increasing costs of additional monetary policy easing, given that asset prices are already elevated in some cases. Additional asset purchases and forward guidance, resulting in still higher asset prices, could intensify eventual corrections in bond and equity markets and associated risk of financial instability, especially if the correction is abrupt. Discounted costs of such future asset price declines will increase as the exit becomes closer. The expected macroeconomic situation may be of some guide in predicting the timing and pace of exit. In this respect, current and projected stronger growth and projected inflation closer to the target in the United States than in the euro area and Japan, and also in the United Kingdom with respect to growth, suggest that exit may come sooner in the United States than in the other countries. However, differences in policy objectives and central bank

7. A larger share of short-term financing creates risks of systemic spillovers related to deleveraging and market-wide fire sales of illiquid assets but measuring it comprehensively is difficult (Stein, 2013).

8. The share of dealer financing of corporate debt securities (largely based on short-term repurchase agreements) is now much lower than the pre-crisis level.

9. Agency mortgage real estate investment trusts in the United States invest in mortgages issued by government agencies rather than in mortgages issued by banks or property per se.

10. The benchmarks include long-term averages of normal and cyclically-adjusted $\mathrm{P} / \mathrm{E}$ ratios (according to the Shiller (2005) approach) and potential levels derived from the Gordon model - see notes under Figure 9. The assessment based on averages is sensitive to the sample selected. For instance, in the United States, starting the sample at the beginning of the $20^{\text {th }}$ century instead of 1980 would lower the average from around 21 to slightly above 16, implying that asset prices in February 2013 were expensive.

11. House prices are overvalued in view of elevated price-to-rent and price-to-income ratios in comparison to long-term averages in Belgium, where prices have been rising gradually, and in France, where prices in recent quarters have declined somewhat following earlier gains. 
reaction functions among these countries may weaken the importance of varying growth and inflation prospects in determining the timing of exit. ${ }^{12}$

\section{Risks of higher inflation}

The risk of unsettling inflation expectations is likely to increase with additional monetary easing. This would be especially the case if markets start doubting that central banks will use available instruments to reduce ample liquidity when needed in the future. ${ }^{13}$ Such fears can arise due to conflicting objectives related, on the one hand, to concerns about financial-market stability and central bank independence which increase with the size of central bank balance sheets (see below) - and, on the other hand, to price stability. Similarly, inflation expectations could rise with forward guidance, if the public interprets conditional promises for maintaining expansionary monetary policy as a sign that the central bank has durably increased its tolerance for higher inflation.

On the basis of the recent developments in inflation expectations, additional asset purchases in the euro area and Japan seem not to pose immediate risks of unanchoring inflation expectations but such risks are higher in the United Kingdom, and, to a lesser extent, the United States. Long-term inflation expectations embedded in prices of financial instruments vary across main OECD countries. They have been broadly stable and in line with the inflation target in the euro area (Figure 11). In Japan, the observed increase in inflation expectations (based on yield differentials between nominal and indexed bonds) is consistent with the new inflation target. In the United States, the widening yield differential between nominal and indexed bonds between mid-2012 and mid-March 2013 pointed to increased inflation expectations but this was not corroborated by expectations derived from inflation swaps and thus may reflect shifting premia. However, in the United Kingdom both measures rose between the mid-2012 and February 2013, indicating some risk of inflation expectations becoming unanchored, especially as inflation has been persistently above the target, though it could also reflect planned changes to the retail price index. ${ }^{14}$

\section{Risks of central bank losses and complexity of exit strategy}

Increasing purchases of government and private bonds expose central banks to bigger losses, and higher interest outlays where reserve balances are remunerated, upon the exit from QE policies and the normalisation of policy rates. For instance, the Federal Reserve could have negative net operating income in the second half of the 2010s, resulting in no remittances to the US Treasury (Carpenter et al., 2013; and Deutsche Bank, 2013). ${ }^{15}$ The deficit will be higher and longer-lasting with a larger stock of accumulated

12. Forward interest rates imply that financial markets expect the first interest rate hikes in the euro area, the United Kingdom and the United States roughly at the same time, i.e. around the middle of 2014.

13. Central banks can use the deposit rate, reverse market operations, term deposits, issuance of central bank bills and required reserves to reduce liquidity. The last option, when combined with the remuneration of reserves below market interest rates, could also help reduce central banks' net interest expenses.

14. Some of the increase in derived inflation expectations could reflect planned changes in the RPI formulae (Bank of England, 2013). Inflation expectations derived from financial instruments are linked to RPI inflation which is higher than CPI inflation due to differences in the formulae. Around mid-2012 revisions to the RPI formulae were considered which would have reduced the wedge between RPI and CPI inflation but in January the revision plans were abandoned. If markets had factored in this technical revision in their inflation expectations, the January announcement would have triggered an immediate correction.

15. For instance, based on market interest rate expectations and additional asset purchases of 1 trillion dollars in 2013, annual net profits (deferred assets) are expected to be negative between 2017 and 2020, peaking at nearly 40 billion dollars in 2019, due to much higher interest expenses (at a peak at 40 billion dollars; the average before the crisis was around 5 billion) and annual capital losses of around 30 billion dollars 
assets, higher future interest rates and a faster pace of disposal of acquired assets. These losses should, however, be viewed against the background of previous high remittances. ${ }^{16}$ Nevertheless, large capital losses, no remittances to the government or high interest payments to banks may be perceived as politically unwelcome, even if central banks could in principle operate with negative equity (Buiter, 2008), and potentially undermine central bank independence. ${ }^{17}$

Additional purchases of assets will complicate the eventual exit from monetary accommodation as starting this process from higher asset holdings could imply more adverse implications for financial stability and central bank independence. Accordingly, such potential marginal costs would tend to be relatively high where the accumulated stock of assets on central banks' balance sheets is high, which is the case for the Federal Reserve, Bank of Japan and the Bank of England (Figure 2 and Table 2). By contrast the stock of assets purchased by the ECB is relatively low so far, with its balance sheet expansion being based on liquidity provision to banks.

\section{Ever-greening and capital misallocation}

Ample and prolonged monetary stimulus may delay the rebalancing of an economy by masking balance sheet weaknesses and undermining incentives for banks to deal with impaired assets. While some forbearance can be desirable in the initial phase of a crisis in order to minimise disruptions to the financial system and the real economy, it may over time allow insolvent banks to remain alive and continue to extend credit to insolvent firms (so-called zombie/forbearance lending or ever-greening). Consequently, this can result in lower economy-wide productivity and potential growth if financing of zombie firms reduces credit to other, more productive, firms, and limits creative destruction, as was the case in Japan in the 1990s (Box 2). Although policy affects the degree of forbearance mainly through banking regulations and supervision, monetary policy stimulus can also play a role in delaying the restructuring of banking sectors. $^{18}$ To the extent that signs of ever-greening are already apparent, additional monetary policy stimulus may prolong and intensify these practices, adding to marginal costs.

(Carpenter et al., 2013). The costs would be substantially higher if QE3 would last until end-2015, since the stock of assets would be $\$ 3$ billion higher than otherwise, i.e. about double the size at the end of 2012.

16. During 2010-14 transfers are estimated to total around 80 billion dollars per year (i.e. around $1 / 2$ per cent of GDP and 4 times larger than on average between 2001 and 2006). To the extent that such profits stem from interest on government bonds, actual government gains are overstated roughly by the amount of interest payments paid by the government to the central bank. In the United States, around half of the Federal Reserve's income in 2011 was attributable to treasury securities and the remaining half to agency debt and mortgage-backed securities.

17. In the United States, accounting rules shield the Federal Reserve's income, operating expenses and capital as negative income is monetised and accounted as deferred assets for government. In Japan, balance-sheet considerations were one of three potential explanations behind the Bank of Japan's reluctance to expand QE programmes in the early 2000s (Ito and Mishkin, 2006).

18. Massive liquidity provisions and low interest rates reduce the opportunity cost of rolling over doubtful loans instead of recognising them as impaired and using scarce equity capital to undertake capital-depleting provisions and write-offs, and they do not distinguish between banks with liquidity problems and insolvent banks. Low interest rates also allow firms on the verge of bankruptcy to continue paying interest on their loans. 


\section{Box 2. Ever-greening in Japan in the 1990s}

The severe economic crisis and the collapse of stock market and real estate prices in Japan in the early 1990s hit bank assets hard. Banks tried initially to avoid reporting problem loans in order to sustain capital positions. This was especially the case in banks with capital ratios close to required regulatory thresholds and with ties to conglomerates (keiretsu relationships) (Peek and Rosengren, 2005). Such practices stemmed also from government pressures on banks, motivated by a desire to limit corporate bankruptcies and thus unemployment, and from the related leniency of bank supervisors. Ever-greening was more prevalent in construction and real estate sectors, where firms with higher debt-asset ratios received more loans but their returns on assets were lower than for other borrowers (Sekine et al., 2003).

The ever-greening-induced survival of zombie firms had negative implications for aggregate productivity as banks provided credit at advantageous terms to troubled clients with lower profitability at the cost of potentially more dynamic borrowers, deterring entries of new and more productive firms. By using industry and firm-level data, Caballero et al. (2008) show that the rise of zombie firms was associated with falling levels of aggregate restructuring (job destruction and creation were smaller in industries with more zombies), while investment and employment growth for healthy firms was negatively related to the proportion of zombie firms in their industry. Besides, in industries where zombie firms prevailed, market shares of inefficient firms were sustained largely due to bank financial support (Ahearne and Shinada, 2005). Model simulations, calibrated on Japanese data, suggest that ever-greening practices may have reduced cumulative aggregate productivity growth in the 1989-99 periods by 1.6 percentage points (Kwon et al., 2009).

Clear evidence on ever-greening in the recent past in the main OECD economies is scant but the evolution of some indicators is suggestive of possible ever-greening practices with important cross-country differences (Figures 12-15): ${ }^{19}$

- In the United States, there is little indication of ever-greening. The post-crisis increase in nonperforming loans (as a share of total loans), bank loan-loss provisions and the number of firm bankruptcies would suggest little forbearance, even if market-to-book ratios in many US banks have remained depressed. The recent decline in the number of bankruptcies and non-performing loans may reflect an end to the destruction process, given the improved economic situation, rather than the emergence of ever-greening practices.

- In Japan, very little change in non-performing loans, loan loss provision and the number of firm bankruptcies since the start of the crisis could indicate some forbearance.

- In Europe there is some indication of ever-greening. Non-performing loans as a share of total loans in France and Germany are similar to their levels in the early 2000s, despite the current much weaker economic situation (OECD, 2012a), and they have been low and increased little in the United Kingdom since the start of the recession. In contrast, they have gone up significantly in several vulnerable euro area countries. In addition, market-to-book ratios have been depressed and loan-loss provisions low in many European banks. Forbearance appears to be of a particular concern in commercial real estate. EBA (2012) argues that in Europe average arrears in commercial real estate did not markedly increase, in spite of the sector's sensitivity to the economic cycle, indicating a possible presence of forbearance. Similarly, around a third of British commercial real estate loans have been subject to forbearance (Bank of England, 2012) and

19. On a macro level, ever-greening could be inferred from the performance of non-performing loans and bankruptcies in relation to a position in the economic cycle. However, a comparison of non-performing loans is difficult due to a lack of long time series and differences in definitions across countries. Similarly, data on bankruptcies are scant and short, and difficult to compare due to different regulatory environments and insolvency procedures and resulting lags between the time of an event that may lead to a bankruptcy and the actual recorded time of the bankruptcy (OECD, 2012b). BIS (2012) argues that depressed market-to-book ratios may be indicative of ever-greening practices. 
only 24 of 122 commercial mortgage-backed security loans in Europe that matured in the first 11 months of 2012 were fully paid at maturity (Fitch, 2012). However, an increase in the number of firm bankruptcies in the United Kingdom and France, and the fact the write-off rates on lending to businesses in the United Kingdom did increase over the past five years, would be less suggestive of ever-greening.

Given scant evidence about the scale of ever-greening, assessing its contribution to recent labour productivity performance remains speculative. Weak aggregate productivity growth would, however, be consistent with ever-greening practices slowing down dynamism. This is especially the case in Europe, where labour productivity growth is significantly weaker than during past recessions, and the levels of labour productivity are still below their pre-crisis levels (Figures 16 and 17). ${ }^{20}$ In the United Kingdom, this pattern seems to be consistent with the Bank of England's (2012) tentative assessment that bank forbearance on existing loans coupled with low policy rates may have contributed to the recent rise in the number of zombie companies.

\section{Market distortions}

Quantitative easing policies could also weaken the functioning of security markets. With large purchases of certain securities (like government and covered bonds or mortgage-backed securities), central banks may become too dominant a buyer (and possibly the only active buyer) and consequently limit liquidity and price discovery as few trades take place among private agents. In addition, during the exit from QE, selling large amounts of purchased securities may unsettle markets. Central banks in Japan, the United Kingdom and the United States already hold a sizeable share of outstanding government bonds or agency and GSE-backed securities, ranging from 15 to 30\% (Table 2). On the other hand, currently the share of their monthly purchases in market transactions is still limited to around $1 \%$ in the United States and Japan, and zero in the United Kingdom where planned purchases have been completed. Despite the low share of transactions, high central bank holdings suggest that further asset purchases in Japan, the United Kingdom and the United States would likely aggravate related market distortions, but less so in the euro area given the low stock of government bonds and private assets held by the ECB.

\section{Spill-overs of monetary stimulus in the main OECD areas to emerging market economies}

Additional stimulus in the main OECD areas can lead to an exchange rate appreciation in foreign economies $^{21}$ but also to higher demand for their exports (Bernanke, 2012). The net marginal benefits for emerging market economies, which are among those most affected, may diminish with increased stimulus. As discussed above, the effectiveness of additional easing measures is likely to fall as they are used more extensively and hence their effectiveness in generating additional demand for emerging market countries. At the same time, a given additional stimulus could put more pressure on appreciation if high valuations of domestic assets prompt investors to increasingly diversify their portfolios into new asset classes, including assets in emerging market economies. Thus, even if monetary easing in the OECD countries may not have had strong impact on the exchange rates of emerging market economies so far, with the nominal effective exchange rate of Brazil, India, Indonesia, Russia and South Africa lower in May 2013 than immediately before the crisis, it might increase with additional monetary stimulus (Figure 18). Indeed, nominal effective exchange rates appreciated between around mid-2012 and May 2013 in many emerging market countries, especially in China and Mexico.

20. Bank forbearance is, however, unlikely to be responsible for the initial large decline in labour productivity in 2008-09 given the abruptness of this decline and the presence of several institutional factors, including short-working-time arrangements in continental Europe, that could better explain this development.

21. Based on event studies, Chen et al. (2012) find some evidence that the US QE programmes lowered bond yields, boosted equity and commodity prices and appreciated domestic currencies in Asian economies. 
In principle, the extent to which capital flows generated by monetary easing in advanced countries prove to be destabilising in destination countries depends on domestic policy settings. Thus, capital inflows should not threaten price stability as long as monetary policy is applied to attain inflation objectives, though this may prove difficult if monetary tightening results in further capital inflows or if the exchange rate is fixed. Also, macro-prudential policy can be applied to guard against excesses in specific asset markets though the effectiveness of such policies is still being tested (Box $1.5 \mathrm{in} \mathrm{OECD,} \mathrm{2013).} \mathrm{Changes} \mathrm{in}$ the monetary/fiscal policy mix may also help deal with capital flows but may compromise domestic policy objectives. As a last resort, temporary capital controls can be used to prevent destabilising capital flows.

In practice, emerging market economies have been able to deal with capital inflows since the onset of the crisis without a major upheaval to economic developments and financial stability. On the back of accelerating capital inflows into many emerging market economies in the second half of 2012 (IIF, 2013) but some moderation in early 2013, credit expansion has surged, prompting the authorities in China to impose restraints on credit expansion. Also, by early 2013 yield spreads between sovereign emerging market bonds and US Treasuries declined to close to their record low levels in 2006-07, likely reflecting in part improved fundamentals as well as capital flows driven by risk-taking. At the same time, equity prices in emerging countries failed to keep up with developments in OECD countries.

The extent to which additional monetary policy easing in OECD countries increases capital inflows and risks of instability will depend on whether domestic policies will continue to respond in an appropriate way. The capacity of emerging markets to cope with capital flows is likely to be tested when OECD countries start exiting, especially if in a sudden manner, from the current accommodative monetary policy stance, with possible large capital outflows from emerging markets.

\section{Conclusions}

Table 3 summarises the assessment of the main benefits and costs of additional easing at present for the four OECD economies which are discussed in the paper. It is based on quantitative criteria to the extent possible but the binary answers to the questions posed to evaluate the costs and benefits inevitably involve a large element of judgement. This applies in particular to the overall assessment. The main conclusions stemming from the analysis presented above are:

- The case for additional stimulus in the United States is weakening. With the output gap expected to narrow and inflation projections not significantly below the target, additional stimulus is not critically needed. Also, doubts about the effectiveness of the latest QE measures in driving interest rates lower point to declining marginal benefits of extra stimulus. Signs of high valuations of several asset classes, including corporate and government bonds, the likely nearness of the required policy change, and the risk that exit could be abrupt and could lead to central bank losses indicate growing marginal costs of the current policy of sustained asset purchases.

- In Japan, potential benefits of extra stimulus are large, given persistent deflation, expected undershooting of the inflation target in 2013 and projected headwinds to growth as fiscal consolidation commences. The recent asset purchases and, in particular, policy announcements were initially effective in lowering long-term interest rates, and raising prices of equities and foreign currencies, though bond yields subsequently returned to their mid-2012 level and the yen exchange rate ceased to depreciate. With little immediate risks of negative consequences, net marginal benefits of extra stimulus seem considerable. In the future, the possibility to raise some asset prices will be ultimately limited when the zero bound for government and corporate bond yields becomes binding.

- In the euro area, disinflationary pressures due to weak growth and the estimated large output gap point to significant potential benefits of further accommodation, especially for members where 
monetary policy transmission is impaired. The scope for cuts in policy rates is limited, however. Improvement of the monetary transmission mechanism would have more mileage but is hard to bring about within the constraints of the current institutional set-up. Specifically, with the OMT functioning on the basis of conditionality, unconditional government bond purchase would be complicated.

- In the United Kingdom, the assessment of the balance of marginal costs and benefits is less clear cut. Doubts about the effectiveness of the latest QE measures, persistent overshooting of the inflation target and some signs of a pick-up in inflation expectations in early 2013 suggest diminishing net marginal benefits. Maintaining the current stimulative stance is, however, justified by weak economic growth and the expected persistent negative large output gap. 


\section{REFERENCES}

Adrian, T. and H. Shin (2009), "Money, Liquidity and Monetary Policy", American Economic Review, Vol. 99, No. 2, pp. 600-605.

Adrian, T. and H. Shin (2010), "Liquidity and Leverage", Journal of Financial Intermediation, Vol. 19, No. 3, pp. 418-437.

Ahearne, A. and N. Shinada, (2005), "Zombie Firms and Economic Stagnation in Japan", International Economics and Economic Policy, Vol. 2, No. 4, pp. 363-381.

Andersson, M. and B. Hofmann (2010), "Gauging the Effectiveness of Central Bank Forward Guidance," in Twenty Years of Inflation Targeting, Cambridge University Press, Cambridge, U.K.

Bank of England (2012), Financial Stability Report, November.

Bank of England (2013), Inflation Report, February.

Bernanke, B. (2012), "US Monetary Policy and International Implications", Remarks at Challenges of the Global Financial System: Risks and Governance under Evolving Globalization, high-level seminar sponsored by the Bank of Japan and IMF, Tokyo, 14 October.

Bernanke, B.S., V.R. Reinhart, and B.P. Sack (2004), "Monetary Policy Alternatives at the Zero Bound: An Empirical Assessment," Brookings Papers on Economic Activity, 2:2004.

BIS (2012), “The Limits of Monetary Policy”, Chapter 4, BIS $82^{\text {nd }}$ Annual Report, June, Bank for International Settlements, Basel, Switzerland.

Bouis, R., L. Rawdanowicz, J-P. Renne, S. Watanabe, A.K. Christensen (2013), "The Effectiveness of Monetary Policy since the Onset of the Financial Crisis", OECD Economics Department Working Papers, No.1081, OECD Publishing.

Buiter, W. (2008), “Can Central Banks Go Broke?”, CEPR Policy Insight, No. 24, May.

Caballero, R., T. Hoshi, and A. Kashyap (2008), "Zombie Lending and Depressed Restructuring in Japan", American Economic Review, Vol. 98, Issue 5, pp. 1943-1977.

Campbell, J.R., C.L. Evans, J.D.M. Fisher, and A. Justiniano (2012), "Macroeconomic Effects of Federal Reserve Forward Guidance," Brookings Papers on Economic Activity, 1:2012.

Carney, M. (2012), “Guidance”, remarks to CFA Society, Toronto, December 2012.

Carpenter, S., J. Ihrig, E. Klee, D. Quinn, and A. Boote (2013), “The Federal Reserve's Balance Sheet and Earnings: A Primer and Projections", Finance and Economics Discussion Series, No. 2013-01, Board of Governors of the Federal Reserve System.

Chen, Q., A. Filardo, D. He, and F. Zhu (2012), "International Spillovers of Central Bank Balance Sheet Policies", BIS Papers, No. 66, October. 
Deutsche Bank (2013), "QE has its Limits", Global Economic Perspectives, Deutsche Bank Global Markets Research, 22 February.

EBA (2012), Final Report on the Implementation of Capital Plans Following the EBA's 2011 Recommendation on the Creation of Temporary Capital Buffers to Restore Market Confidence, European Banking Authority, October.

Eggertsson, G.B., and M. Woodford (2003), "The Zero Bound on Interest Rates and Optimal Monetary Policy," Brookings Papers on Economic Activity, 1:2003.

ESMA (2013), ESMA Report on Trends, Risks and Vulnerabilities, No. 1, European Securities and Markets Authority, February.

Farhi, E., and J. Tirole (2012), "Collective Moral Hazard, Maturity Mismatch, and Systemic Bailouts", American Economic Review, Vol. 102, No. 1, pp. 60-93.

Fitch (2012), “2012 EMEA CMBS Loan Outcomes Foreshadow a Tough 24 Months”, Fitch Wire, 4 December.

Girouard, N., M. Kennedy and C. André (2006), "Has the Rise in Debt Made Households More Vulnerable?", OECD Economics Department Working Papers, No. 535, OECD Publishing.

Goodhart, C. and J. Ashworth (2012), "QE: A Successful Start May Be Running into Diminishing Returns", Oxford Review of Economic Policy, Vol. 28, No. 4, pp. 640-670.

Hahm, J., F. Mishkin, H. Shin, and K. Shin (2012), "Macroprudential Policies in Open Emerging Economies", NBER Working Papers, No. 17780.

He, Z. (2010), "Evaluating the Effect of the Bank of Canada's Conditional Commitment", Bank of Canada Policy Discussion Papers, No. 2010-11.

IIF (2013), "Capital Flows to Emerging Market Economies”, IIF Research Note, January 22.

Ito, T., and F. Mishkin (2006), "Two Decades of Japanese Monetary Policy and the Deflation Problem", in T. Ito and A. Rose (eds) "Monetary Policy under Very Low Inflation in the Pacific Rim", NBER East Asia Seminar on Economics, Vol. 15, Chicago: University of Chicago Press, pp. 131-193.

Johansson, A., Y. Guillemette, F. Murtin, D. Turner, G. Nicoletti, C. de la Maisonneuve, P. Bagnoli, G. Bousquet, and F. Spinelli (2012), "Long-Term Growth Scenarios", OECD Economics Department Working Papers, No. 1000, OECD Publishing.

Kwon, H., F. Narita, and M. Narita (2009), "Resource Reallocation and Zombie Lending in Japan in the '90s", RIETI Discussion Paper Series, No. 09-E-052.

Martin, C. and C. Milas (2012), "Quantitative Easing: A Sceptical Survey", Oxford Review of Economic Policy, Vol. 28, No. 4, pp. 750-764.

Minegishi, M. and B. Cournède (2010), "Monetary Policy Responses to the Crisis and Exit Strategies", OECD Economics Department Working Papers, No. 753, OECD Publishing.

Moessner, R. and W.R. Nelson (2008), "Central Bank Policy Rate Guidance and Financial Market Functioning," International Journal of Central Banking, Vol. 4, No. 4.

OECD (2012a), OECD Economic Outlook, No. 91, OECD Publishing. 
ECO/WKP(2013)74

OECD (2012b), Entrepreneurship at a Glance 2012, OECD Publishing.

OECD (2013), OECD Economic Outlook, No. 93, OECD Publishing.

Peek, J. and E. Rosengren (2005), "Unnatural Selection: Perverse Incentives and the Misallocation of Credit in Japan", American Economic Review, Vol. 95, No. 4, pp. 1144-1166.

Rajan, R. (2005), “Has Financial Development Made the World Riskier?" in The Greenspan Era: Lessons for the Future, Federal Reserve Bank of Kansas City, pp. 313-369.

Rajan, R. (2006), “Has Finance Made the World Riskier?”, European Financial Management, Vol. 12, No. 4, pp. 499-533.

Sekine, T., K. Kobayashi, and Y. Saita, (2003), "Forbearance Lending: The Case of Japanese Firms," Bank of Japan Monetary and Economic Studies, Vol. 21, No. 2, pp. 69-92.

Shiller, R. (2005), Irrational Exuberance, Princeton University Press, Princeton, New Jersey.

Stein, J. (2013), "Overheating in Credit Markets - Origins, measurement, and Policy Responses", Speech at the "Restoring household financial stability after the Great Recession - why household balance sheets matter", research symposium, St. Louis, Missouri, 7 February.

Svensson, L. (2009), "Transparency under Flexible Inflation Targeting: Experiences and Challenges", Sveriges Riksbank Economic Review, 2009:1.

Williams, J.C. (2011), "Unconventional Monetary Policy: Lessons from the Past Three Years," FRBSF Economic Letter, 2011-31.

Woodford, M. (2012), "Methods of Policy Accommodation at the Interest-Rate Lower Bound", paper presented at The Changing Policy Landscape: A Symposium Sponsored by the Federal Reserve Bank of Kansas City, Jackson Hole, Wyoming.

Yellen, J. (2012), "Revolution and Evolution in Central Bank Communications", speech at the Haas School of Business, Berkeley, November 2012. 
ECO/WKP(2013)74

\section{ANNEX 1. TABLES AND FIGURES}

Table 1. Housing market developments

\begin{tabular}{|c|c|c|c|c|c|c|c|}
\hline & \multicolumn{4}{|c|}{ Per cent annual rate of change } & \multicolumn{2}{|c|}{$\begin{array}{l}\text { Level relative to } \\
\text { long-term average }\end{array}$} & \multirow[b]{2}{*}{$\begin{array}{c}\text { Latest } \\
\text { available } \\
\text { quarter }\end{array}$} \\
\hline & $\begin{array}{c}2004- \\
2010\end{array}$ & 2011 & $2012^{2}$ & $\begin{array}{c}\text { Latest } \\
\text { quarter }^{3}\end{array}$ & $\begin{array}{l}\text { Price-to- } \\
\text { rent } \\
\text { ratio }\end{array}$ & $\begin{array}{l}\text { Price-to- } \\
\text { income } \\
\text { ratio }\end{array}$ & \\
\hline United States & -2.3 & -6.5 & 1.6 & 5.4 & 100 & 88 & Q1 2013 \\
\hline Japan & -2.1 & -2.4 & -2.1 & -1.3 & 62 & 64 & Q1 2013 \\
\hline Germany & -0.8 & 3.3 & 3.8 & 3.6 & 88 & 82 & Q1 2013 \\
\hline France & 3.6 & 3.8 & -2.3 & -2.3 & 134 & 132 & Q1 2013 \\
\hline Italy & 0.7 & -2.1 & -5.3 & -6.8 & 99 & 112 & Q4 2012 \\
\hline United Kingdom & 0.6 & -5.2 & -1.0 & -0.4 & 131 & 123 & Q1 2013 \\
\hline Canada & 5.6 & 2.7 & 3.6 & 1.8 & 164 & 130 & Q1 2013 \\
\hline Australia & 3.7 & -4.9 & -2.9 & -0.1 & 137 & 121 & Q1 2013 \\
\hline Austria & 2.2 & 0.7 & 9.2 & 8.4 & 112 & 115 & Q4 2012 \\
\hline Belgium & 4.9 & 0.0 & -0.2 & -0.8 & 161 & 148 & Q4 2012 \\
\hline Czech Republic & & -0.4 & -3.7 & -2.4 & 91 & 95 & Q4 2012 \\
\hline Denmark & 2.4 & -5.1 & -5.6 & -2.0 & 112 & 108 & Q4 2012 \\
\hline Finland & 2.8 & -0.6 & -1.0 & -0.9 & 136 & 99 & Q1 2013 \\
\hline Greece & 0.4 & -8.6 & -12.5 & -10.7 & 82 & 108 & Q1 2013 \\
\hline Iceland & & 0.5 & 1.3 & -0.2 & 95 & & Q4 2012 \\
\hline Ireland & -1.7 & -14.4 & -14.3 & -4.0 & 88 & 85 & Q1 2013 \\
\hline Israel & 3.6 & 7.1 & 1.3 & 4.6 & 111 & & Q4 2012 \\
\hline Korea & 1.1 & 1.4 & 0.7 & -1.8 & 106 & 62 & Q1 2013 \\
\hline Luxembourg & & 1.5 & 2.9 & 2.0 & 106 & 104 & Q4 2012 \\
\hline Netherlands & 0.3 & -4.5 & -8.4 & -10.8 & 111 & 123 & Q1 2013 \\
\hline Norway & 5.0 & 6.6 & 5.8 & 5.2 & 171 & 127 & Q1 2013 \\
\hline New Zealand & 2.4 & -1.8 & 3.5 & 5.4 & 161 & 125 & Q4 2012 \\
\hline Portugal & 0.2 & -3.8 & -4.1 & -3.4 & 87 & 93 & Q1 2013 \\
\hline Slovak Republic & & -6.7 & -4.6 & -2.4 & 95 & 88 & Q1 2013 \\
\hline Slovenia & & 1.0 & -8.6 & -10.4 & 89 & 92 & Q4 2012 \\
\hline Spain & 0.4 & -8.8 & -11.0 & -10.0 & 108 & 114 & Q1 2013 \\
\hline Sweden & 5.5 & -0.5 & -2.4 & 2.8 & 132 & 122 & Q1 2013 \\
\hline Switzerland & 1.8 & 4.0 & 4.2 & 4.5 & 100 & 93 & Q1 2013 \\
\hline Total of above euro area ${ }^{4,5}$ & 1.0 & -0.8 & -2.8 & -2.6 & 108 & 109 & Q1 2013 \\
\hline Total of above countries ${ }^{5}$ & -0.3 & -3.2 & -0.4 & 1.3 & 103 & 95 & Q1 2013 \\
\hline
\end{tabular}

Note: House prices deflated by the private consumption deflator.

1. Average from 1980 (or earliest available date) to latest quarter available $=100$.

2. Average of available quarters where full year is not yet complete.

3. Increase over a year earlier to the latest quarter available.

4. Germany, France, Italy, Austria, Belgium, Finland, Greece, Ireland, the Netherlands, Portugal, the Slovak Republic, Slovenia and Spain.

5. Using 2010 GDP weights, calculated using latest country data available.

Source: Girouard et al. (2006) and OECD. 
Table 2. Composition of central bank balance sheets

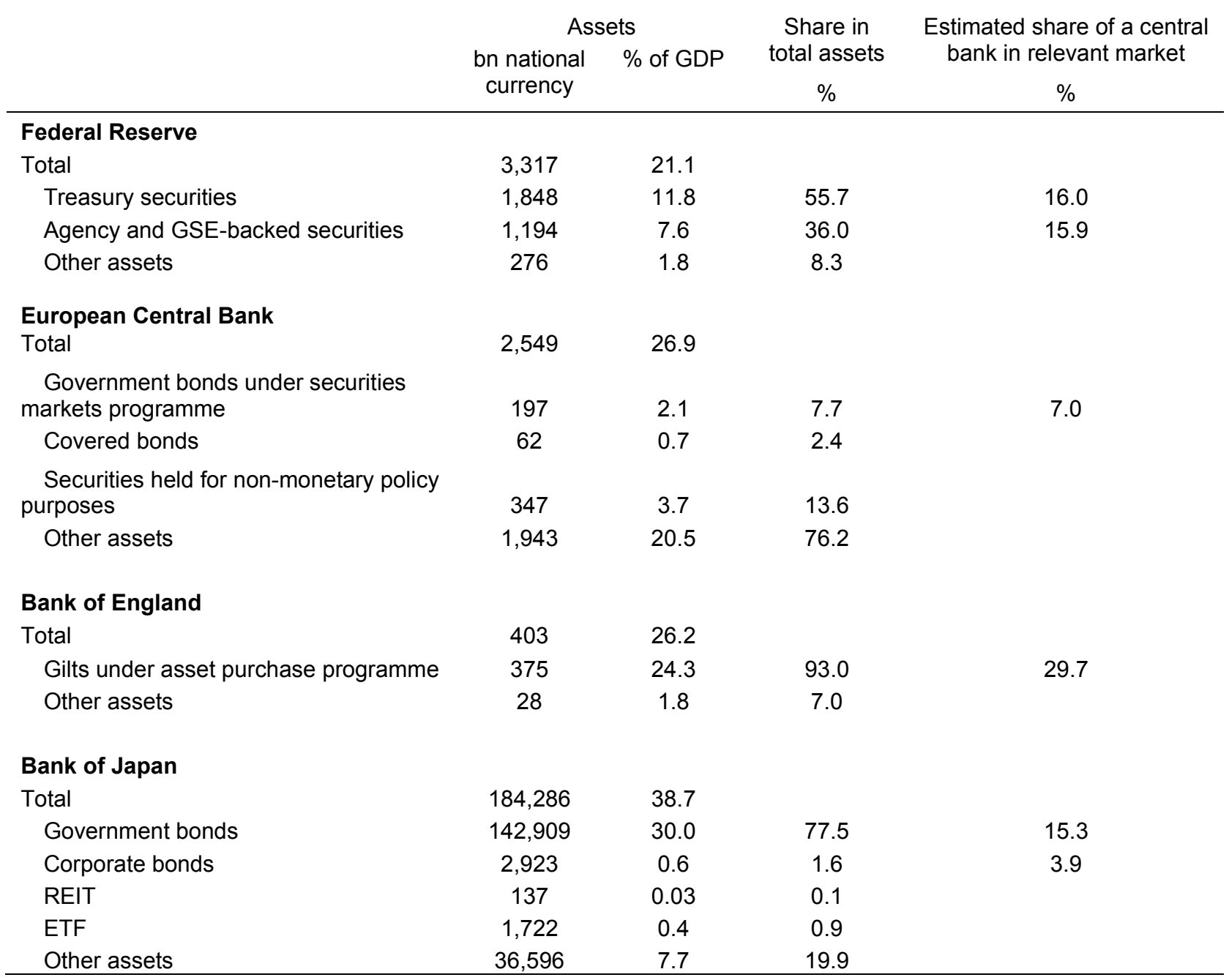

Note: Data are as of May 2013.

Source: Bank of England, Bank of Japan, Datastream, ECB, Federal Reserve, and OECD. 
Table 3. Framework of assessing benefits and costs of additional monetary stimulus

"+" implies that a positive answer to the questions supports additional stimulus, "-“ vice versa, and "?" means that implications are unclear

\begin{tabular}{|c|c|c|c|c|}
\hline & $\begin{array}{l}\text { United } \\
\text { States }\end{array}$ & Japan & $\begin{array}{l}\text { Euro } \\
\text { area }\end{array}$ & $\begin{array}{c}\text { United } \\
\text { Kingdom }\end{array}$ \\
\hline \multicolumn{5}{|l|}{$\begin{array}{l}\text { Have recent asset purchases lowered the yields of purchased } \\
\text { assets (suggesting their effectiveness)? }\end{array}$} \\
\hline Government bonds & - & + & + & - \\
\hline Mortgage-backed securities & - & na & na & na \\
\hline $\begin{array}{l}\text { Have credit conditions eased recently (implying improving } \\
\text { bank lending channel and thus more effective additional } \\
\text { stimulus)? }\end{array}$ & + & + & - & + \\
\hline $\begin{array}{l}\text { Is the estimated slack currently high (indicating potential large } \\
\text { benefits of effective extra stimulus)? }\end{array}$ & + & $?$ & + & + \\
\hline $\begin{array}{l}\text { Is the output gap expected to widen going forward (indicating } \\
\text { potential large benefits of effective extra stimulus)? }\end{array}$ & - & + & + & - \\
\hline $\begin{array}{l}\text { Are inflation projections significantly below targets in } 2013 \\
\text { (indicating potential large benefits of effective extra stimulus)? }\end{array}$ & - & + & + & - \\
\hline \multicolumn{5}{|l|}{$\begin{array}{l}\text { Are asset prices subdued at present (suggesting less } \\
\text { immediate risks of excessive asset valuations) / Are asset } \\
\text { prices falling at present? }\end{array}$} \\
\hline Government bonds & $-I-$ & $-I-$ & $-I-$ & $-I-$ \\
\hline Corporate bonds & $-1-$ & $-I-$ & $-I-$ & $-1-$ \\
\hline Equities & $-1-$ & $-I-$ & $-I-$ & $-I-$ \\
\hline Property & $+1-$ & $+1+$ & $? /+$ & $-I-$ \\
\hline $\begin{array}{l}\text { Are inflation expectations aligned with or converging to targets } \\
\text { (indicating little risks to unanchoring inflation expectations)? }\end{array}$ & $?$ & + & + & - \\
\hline $\begin{array}{l}\text { Are possible losses for the central bank small (implying little } \\
\text { threat to its independence)? }\end{array}$ & - & - & + & - \\
\hline $\begin{array}{l}\text { Is the start of exit likely only after three years (implying that } \\
\text { some costs may materialise late)? }\end{array}$ & - & $?$ & $?$ & $?$ \\
\hline $\begin{array}{l}\text { Is the incidence of non-performing loans high at present } \\
\text { (suggesting little ever-greening)? }\end{array}$ & + & - & - & - \\
\hline Are bankruptcies high (suggesting little ever-greening)? & + & - & - & + \\
\hline $\begin{array}{l}\text { Is the central bank still a small buyer in the targeted markets } \\
\text { (implying little risk of market distortions)? }\end{array}$ & - & - & + & - \\
\hline Overall assessment & - & + & + & $?$ \\
\hline
\end{tabular}

Source: OECD. 
Figure 1. Policy interest rates

Last observation: 31 May 2013

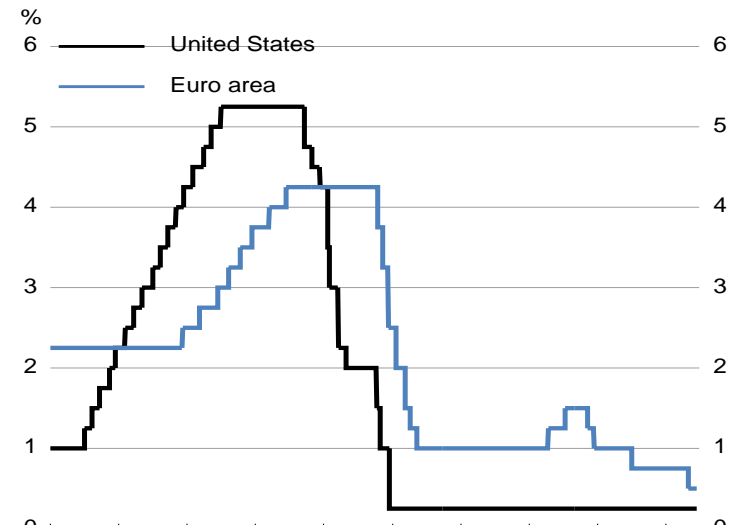

$0 \longdiv { 2 0 0 4 2 0 0 5 2 0 0 6 2 0 0 7 2 0 0 8 2 0 0 9 2 0 1 0 2 0 1 1 2 0 1 2 }$

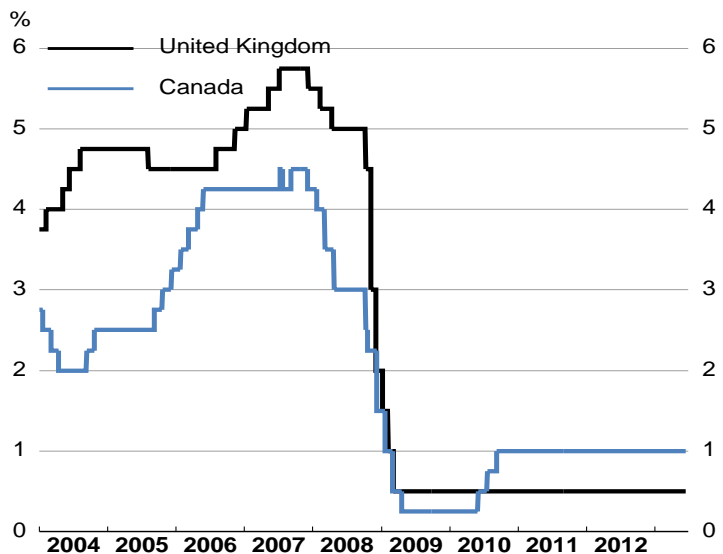

0 2004 20052006200720082009201020112012 ' 0
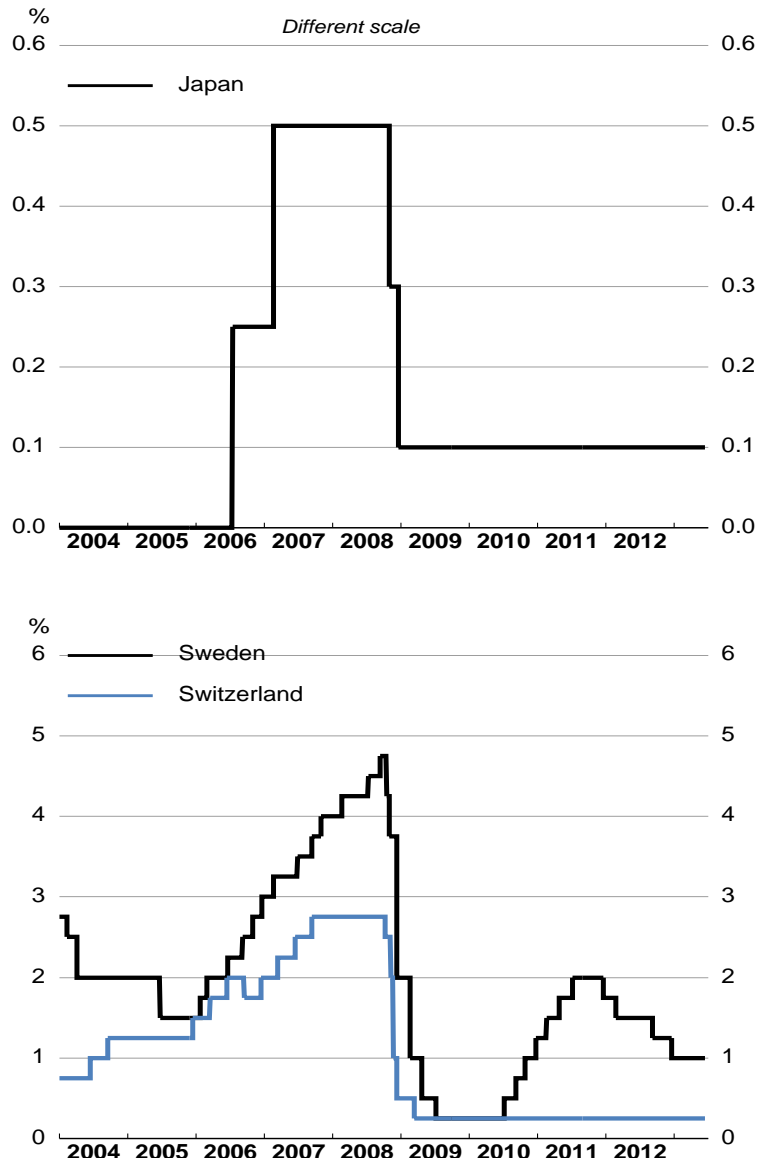

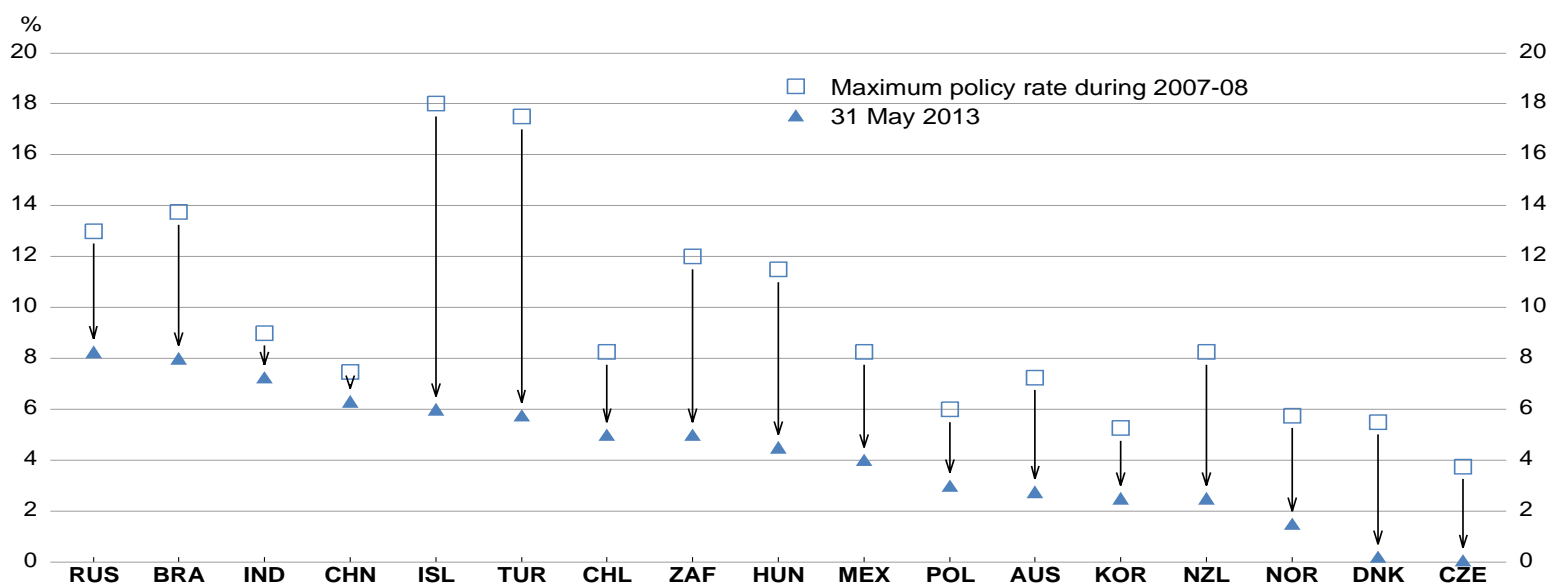

Note: The policy interest rates are: the Federal Funds target rate for the United States the uncollateralised overnight call rate for Japan; the ECB main refinancing operations of fixed rate tenders for the euro area; the official Bank of England rate for the United Kingdom; the target for the overnight rate for Canada; the Riksbank repo rate for Sweden and the reference interest rate of the target range, the three-month Swiss franc Libor, for Switzerland.

Source: Central banks. 
Figure 2. Central bank assets

\% of GDP (Last observation: May 2013)
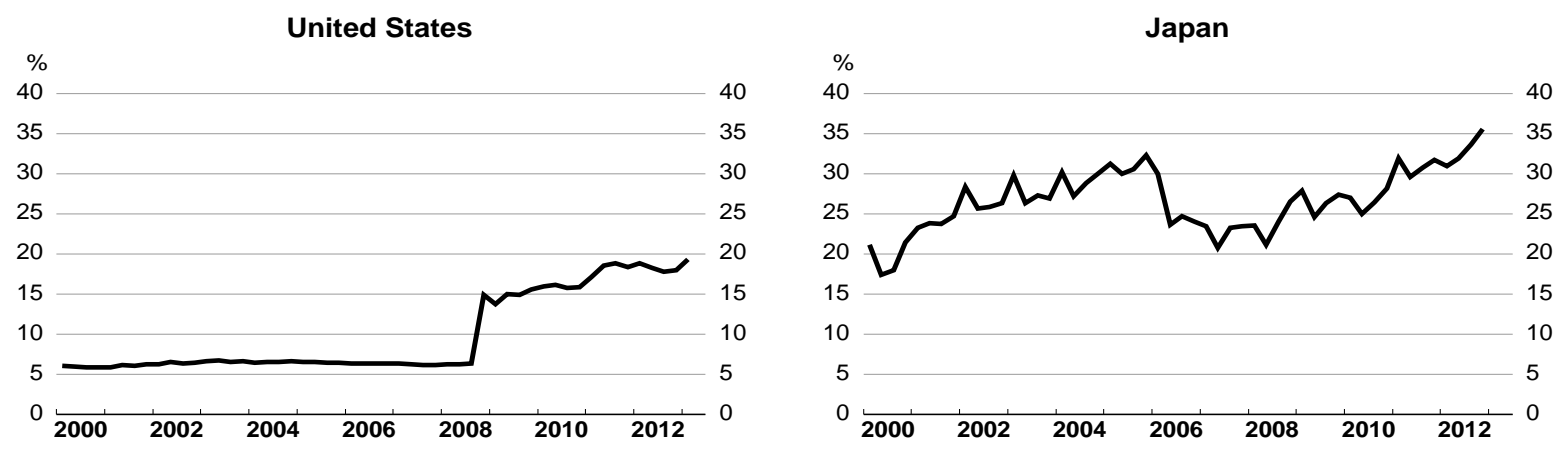

Euro area
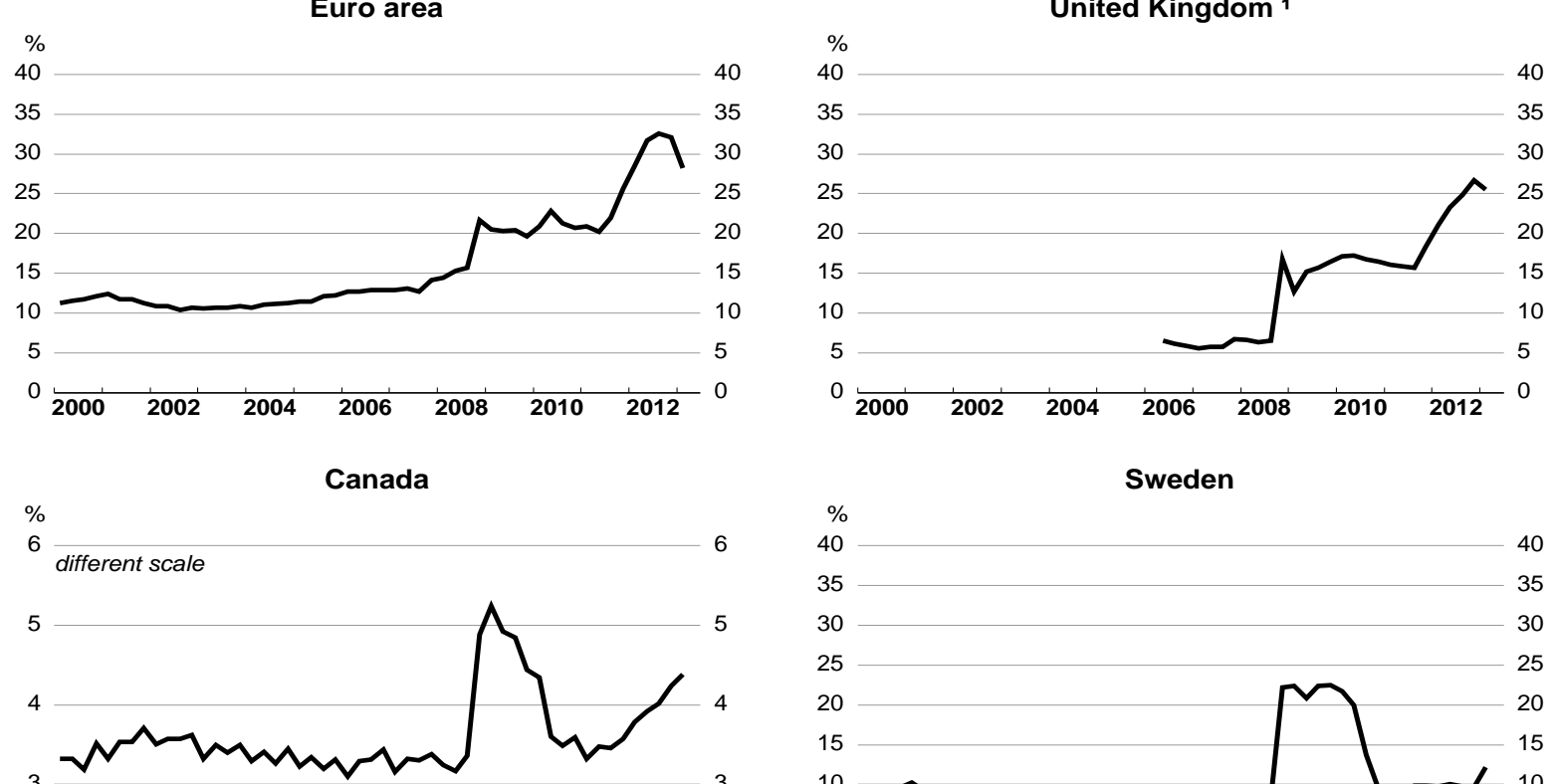

2 2000 $2002 \quad 2004 \quad 2006 \quad 2008 \quad 2010 \quad 2012{ }^{\prime} 2$
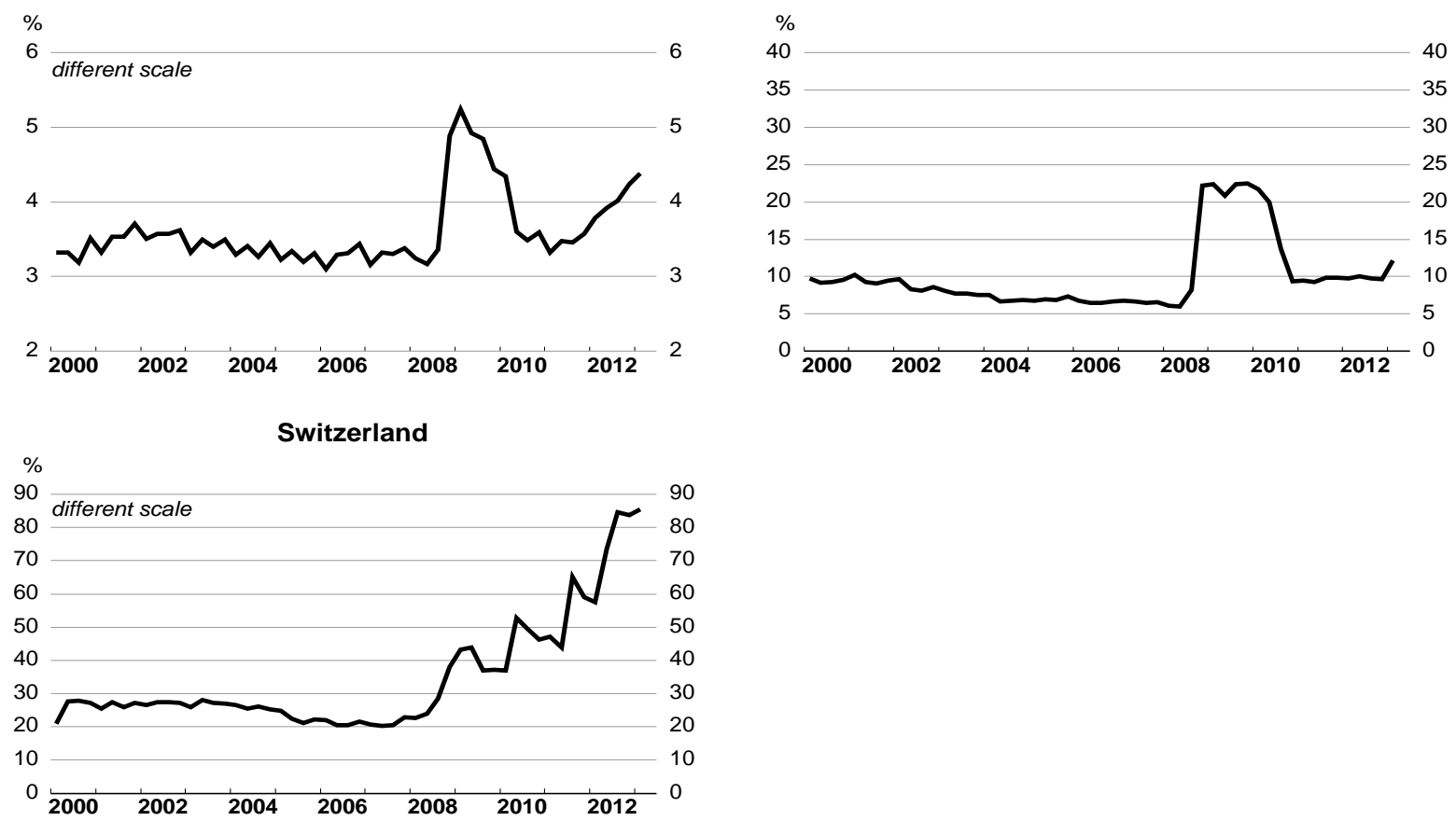

1. The Bank of England does not report consolidated balance sheets before 2006 .

Source: Datastream and central banks. 
Figure 3. Ten-year government bond yields

Last observation: May 2013

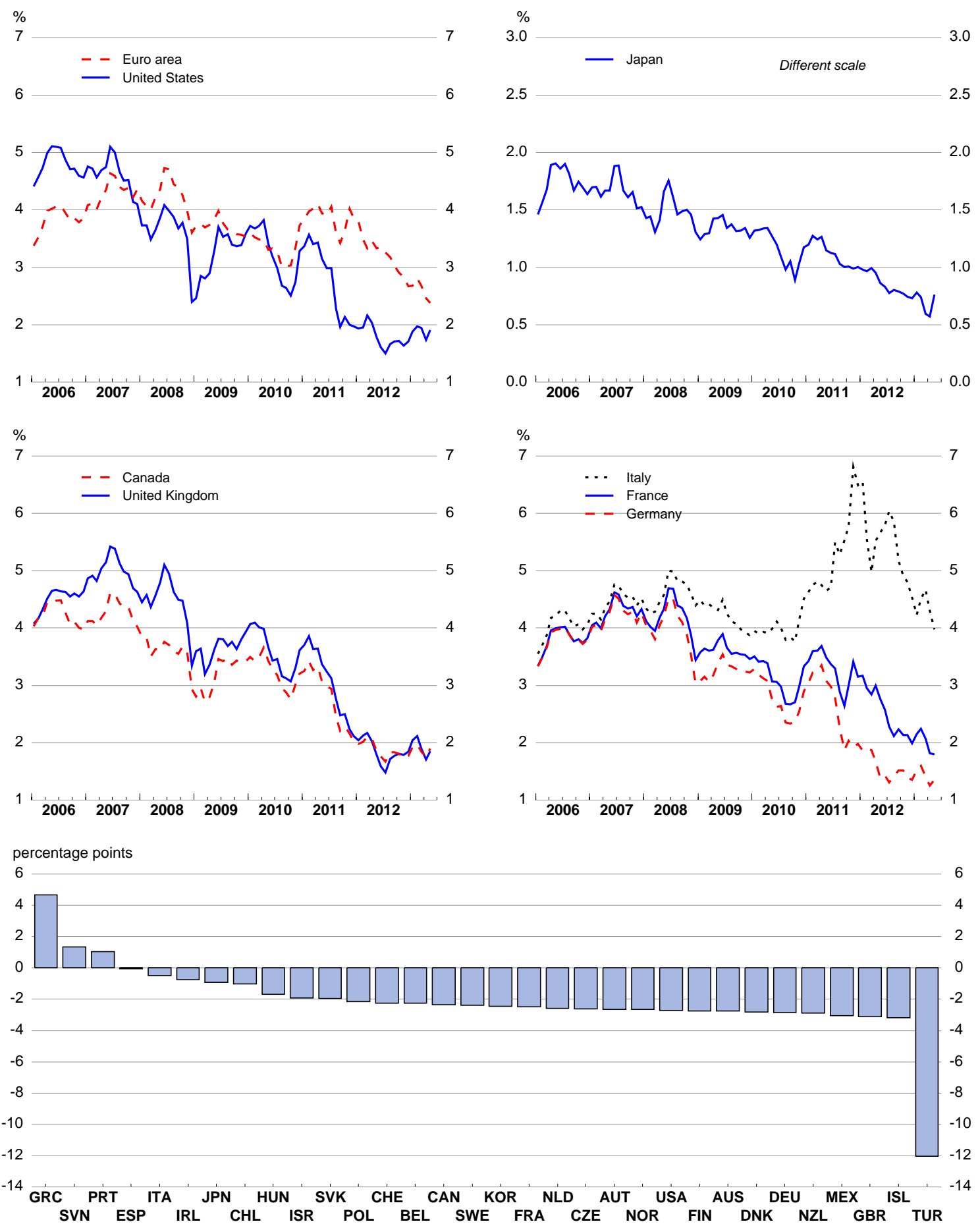

1. The change is calculated as a difference between the average for 2007 and the average for May 2013 .

Note: Monthly averages.

Source: Datastream and OECD Economic Outlook 93 database. 
Figure 4. Government and MBS bond yields at various maturities

Last observation: 31 May 2013

United States

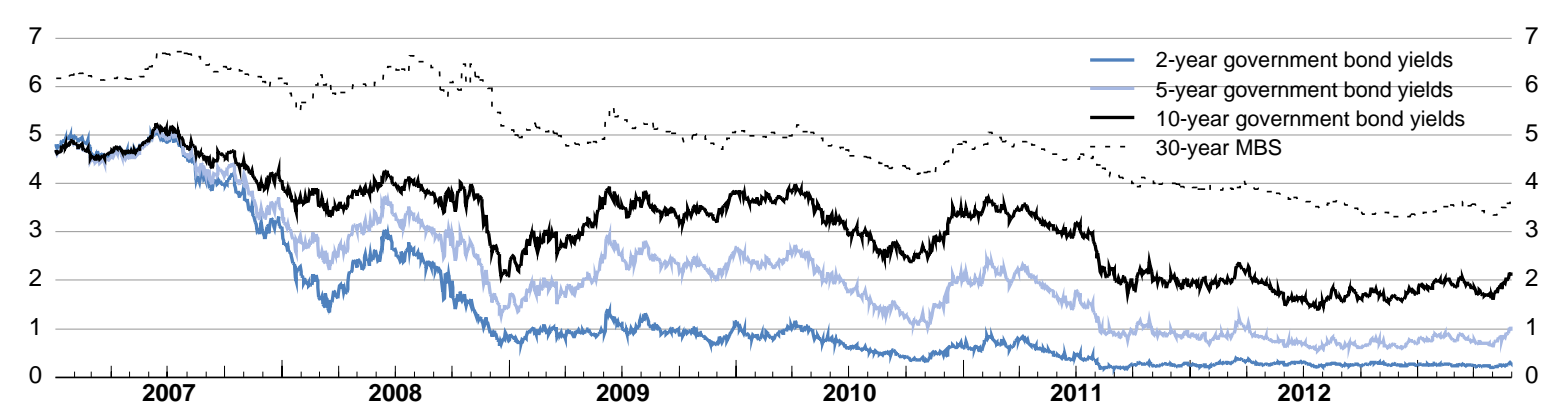

Japan

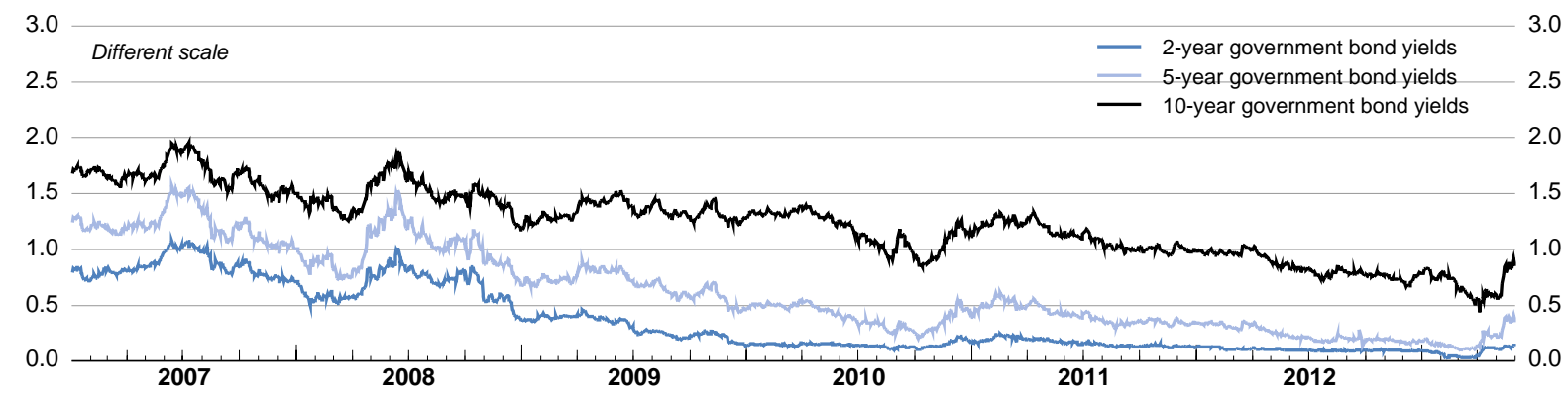

United Kingdom

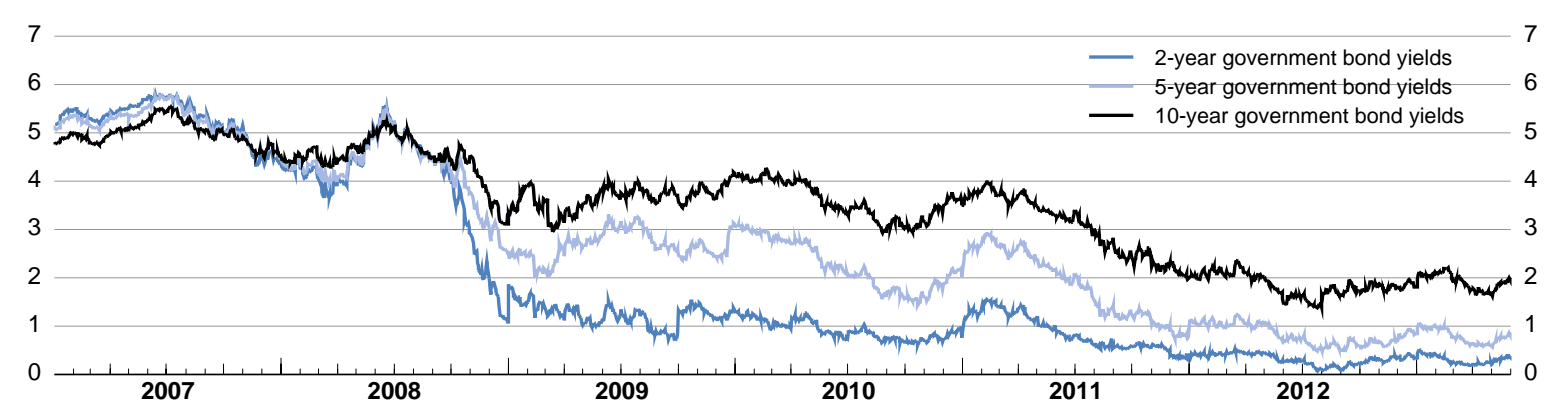

Source: Datastream. 
$\mathrm{ECO} / \mathrm{WKP}(2013) 74$

Figure 5. Changes in bond yields on the announcement of asset purchases

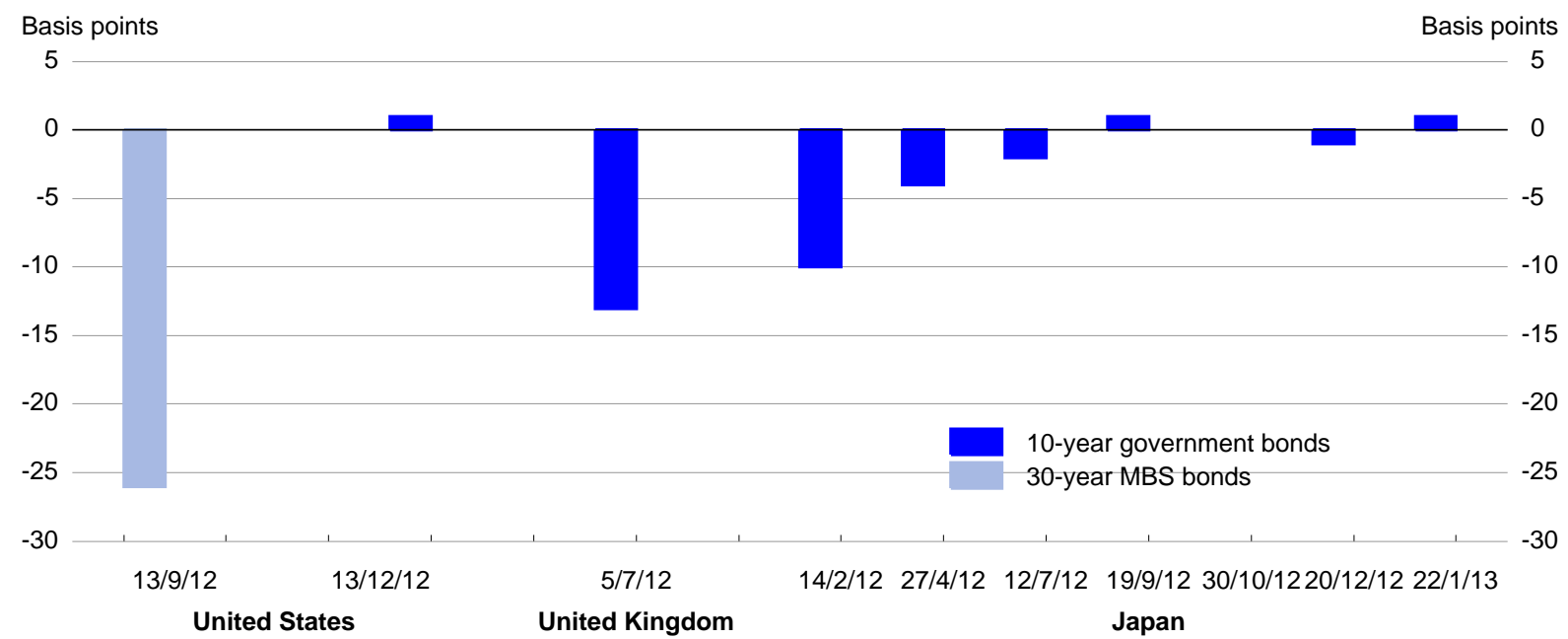

Note: Changes are calculated as a difference in yields between the day of the policy announcement and the day after the announcement.

Source: Datastream. 
Figure 6. Long-term interest rates and their long-term trends

Last observation: 2013Q2

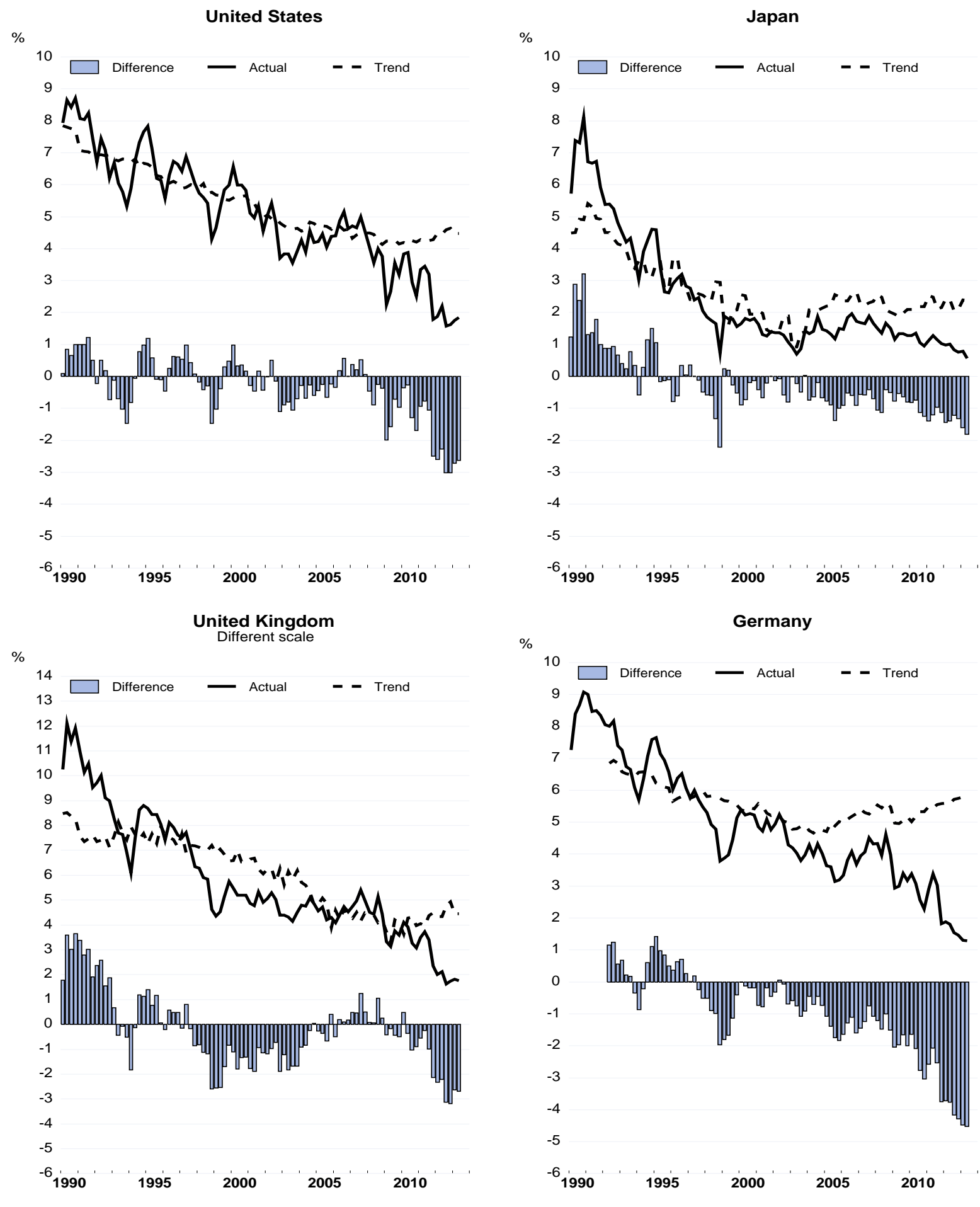

Note: Trend rates are calculated by adding OECD's per capita potential growth estimates to long-term inflation consensus forecasts and removing mean differences between the series obtained and the actual long-term rates.

Source: OECD Economic Outlook 93 database. 
Figure 7. Corporate bond spreads

Percentage points (Last observation: 31 May 2013)

United States

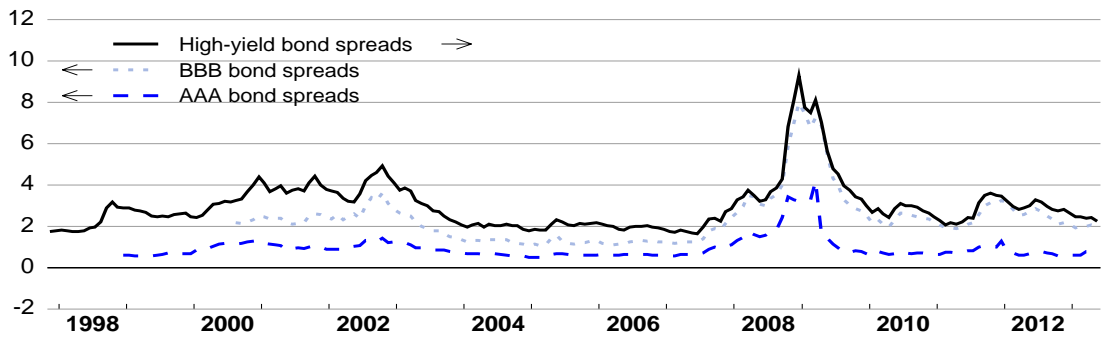

Euro area

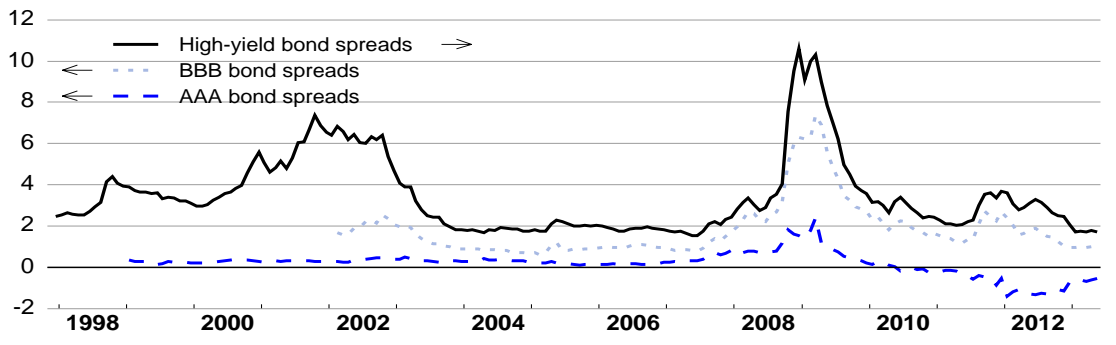

Japan

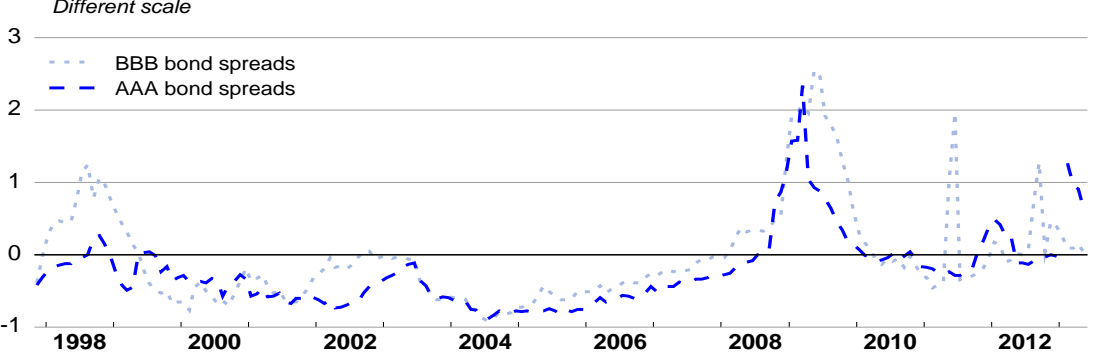

United Kingdom
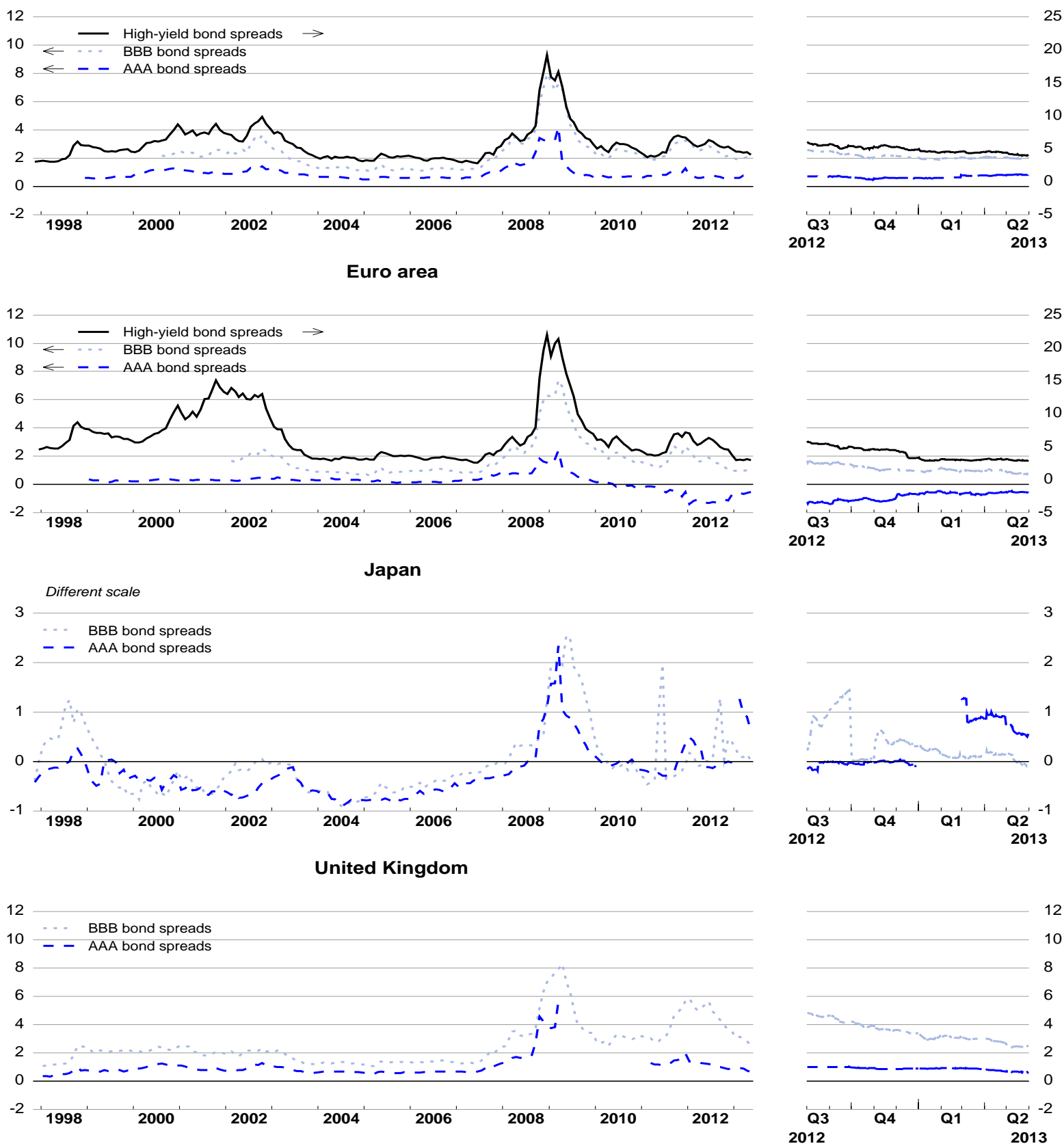

Note: Spreads of high-yield bonds (Merrill Lynch indices) less government bond yields (10-year benchmark bonds). Spreads of corporate BBB rated bonds (Merrill Lynch) based on average yields for 5-7 years and for 7-10 years less average government bond yields of same maturities. Spreads of corporate AAA rated bonds (Merrill Lynch for the United States and the United Kingdom; IBOXX for the euro area) based on 7-10 year yields less government bond yields of the same maturity. For Japan the spreads of corporate AAA and BBB are less government bond yields (10-year benchmark bonds. The spike in Japanese BBB bonds yields in early 2011 is related to the earthquake and its aftermath.

Source: Datastream; OECD calculations. 


\section{Figure 8. Gross corporate bond issuance}

In billions of national currency

United States
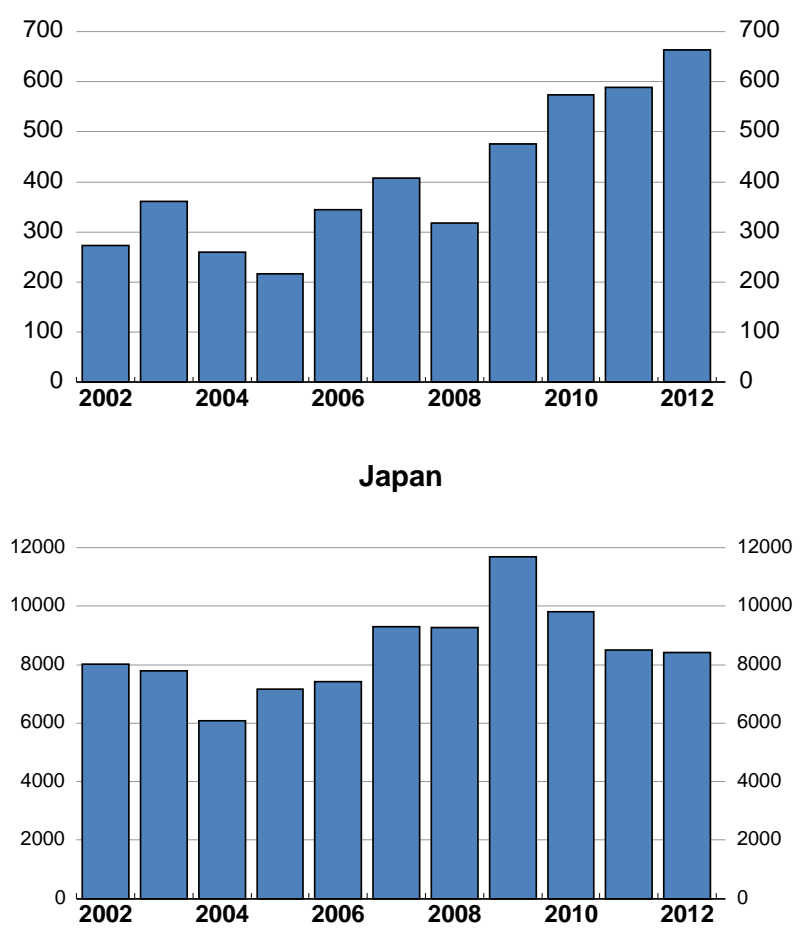

Euro area ${ }^{1}$

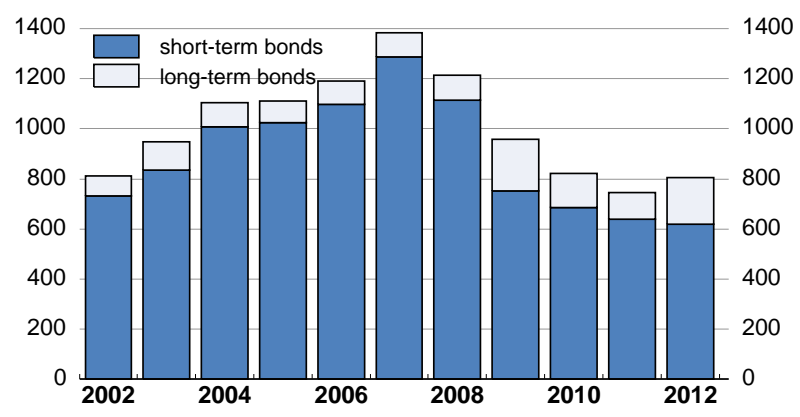

United Kingdom

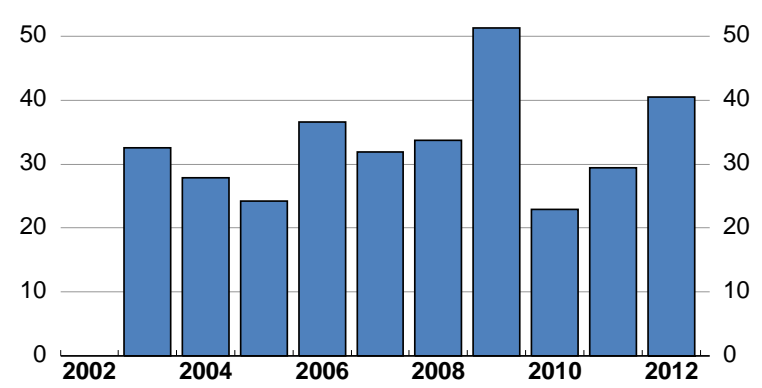

Note: Gross issuance of bonds of private non-financial corporations except Japan (publicly-offered private bonds). For the United Kingdom, the sum of all currency programme and stand-alone bonds. For the euro area (changing composition of member countries) of all currency for non-financial corporations.

1. Short-term means securities with an original maturity of one year or less (in exceptional cases two years or less). Securities with a longer original maturity, or with optional maturity dates, the latest of which is more than one year away, or with indefinite maturity dates, are classified as long-term.

Source: Bank of England, Federal Reserve, ECB and Japan Securities Dealers Association (JSDA). 
Figure 9. Price-to-earnings ratios

Last observation: 2013Q2

\section{United States}
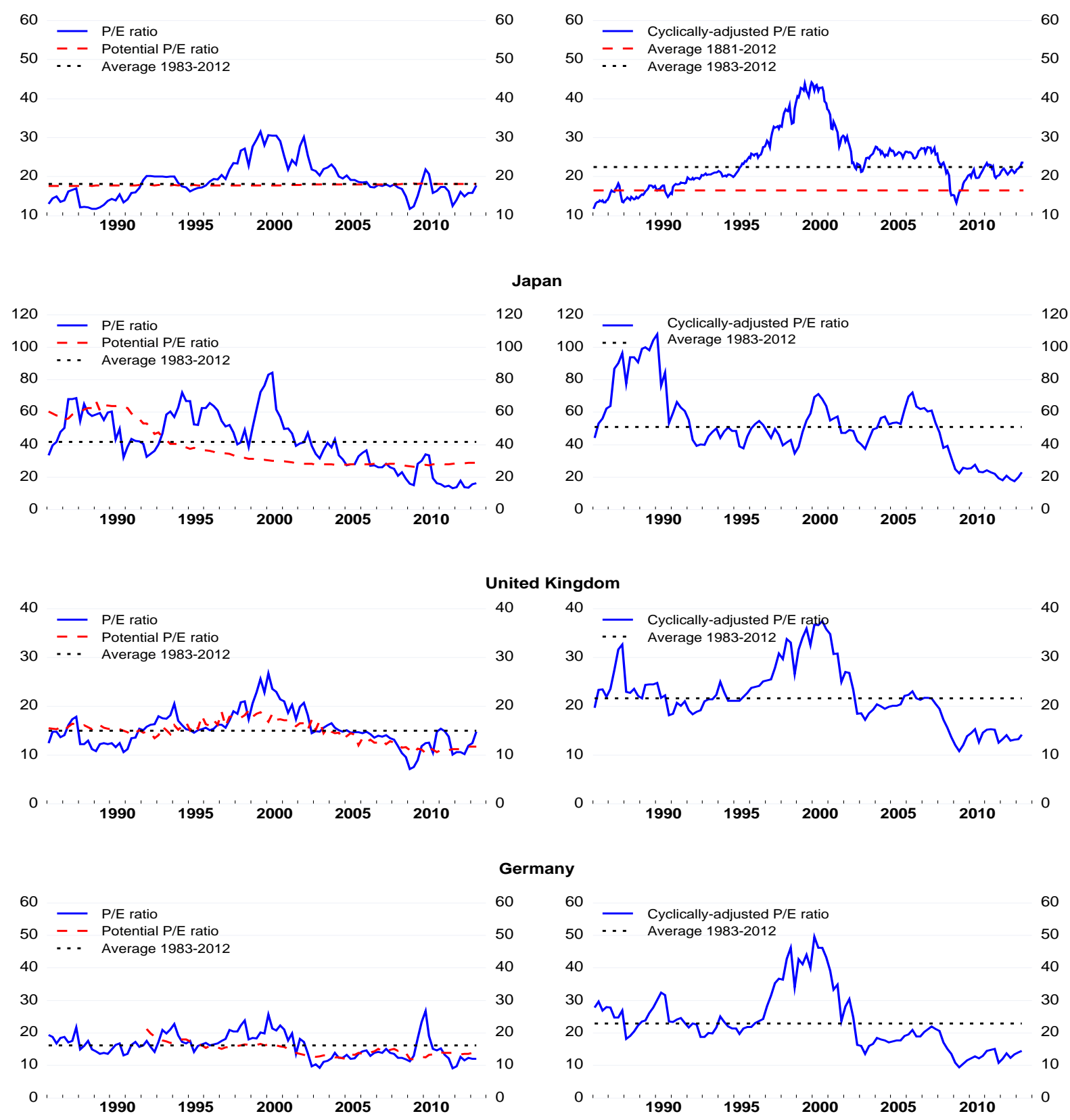

Germany

Note: Potential P/E ratios are calculated by replacing dividend growth with the OECD's potential output growth in the traditional Gordon growth model where the price-to-earnings ratio is represented as the inverse of the difference between the constant required return and dividend growth, multiplied by a coefficient. The impact of potential output growth on the price-to-earnings ratio depends on the estimated coefficient. In the case of the United States, since the coefficient is very small and not statistically significant, the potential price-earnings ratio fluctuates little and is very close to the average.

Source: Robert Shiller's website, Datastream, OECD. 


\section{Figure 10. Real house prices}

Real house price (index 2007Q1=100) (Last observation: 2013Q1)

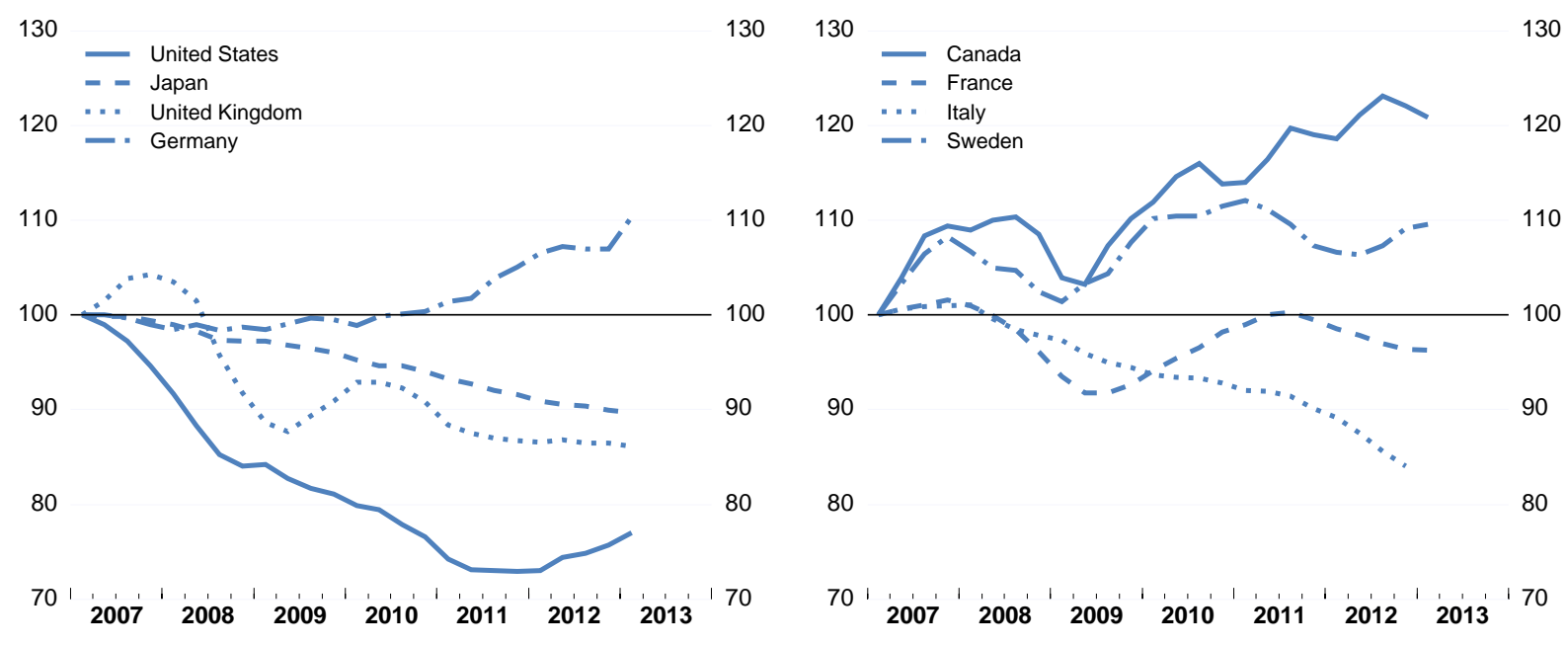

Growth in real house prices from 2007Q1 to 2013Q1

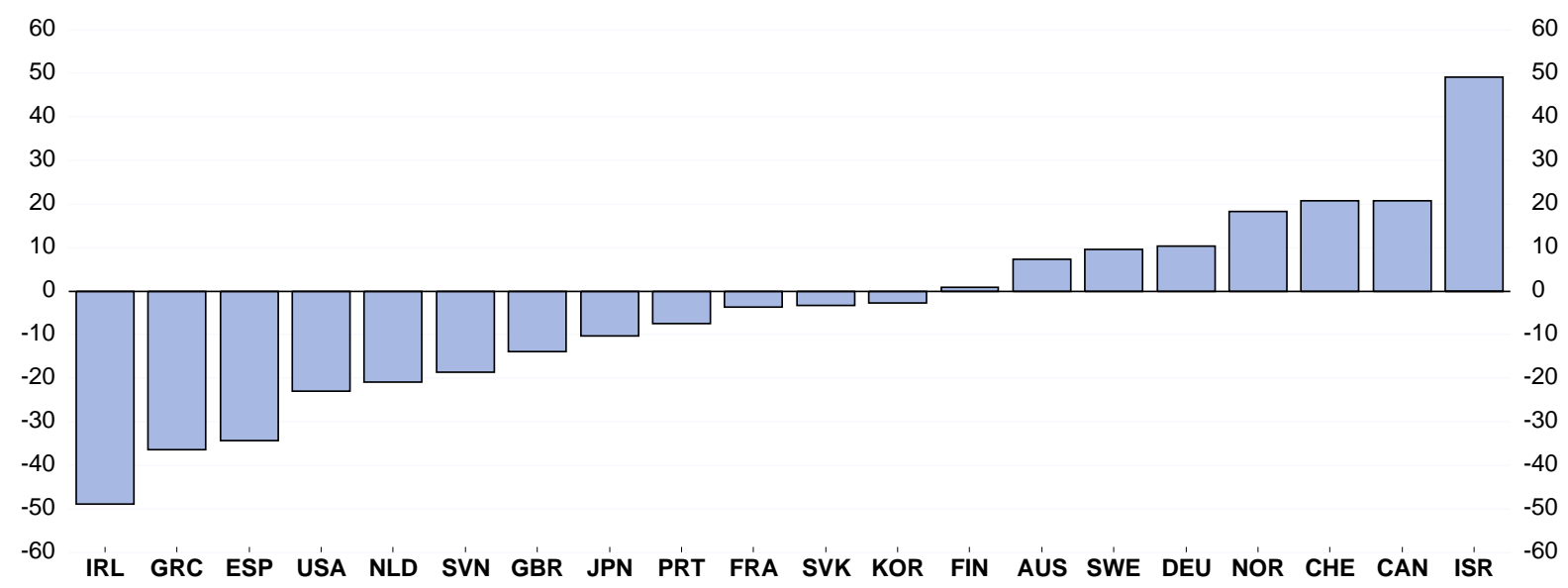

Source: OECD. 


\section{Figure 11. Inflation expectations}

Last observation: May 2013
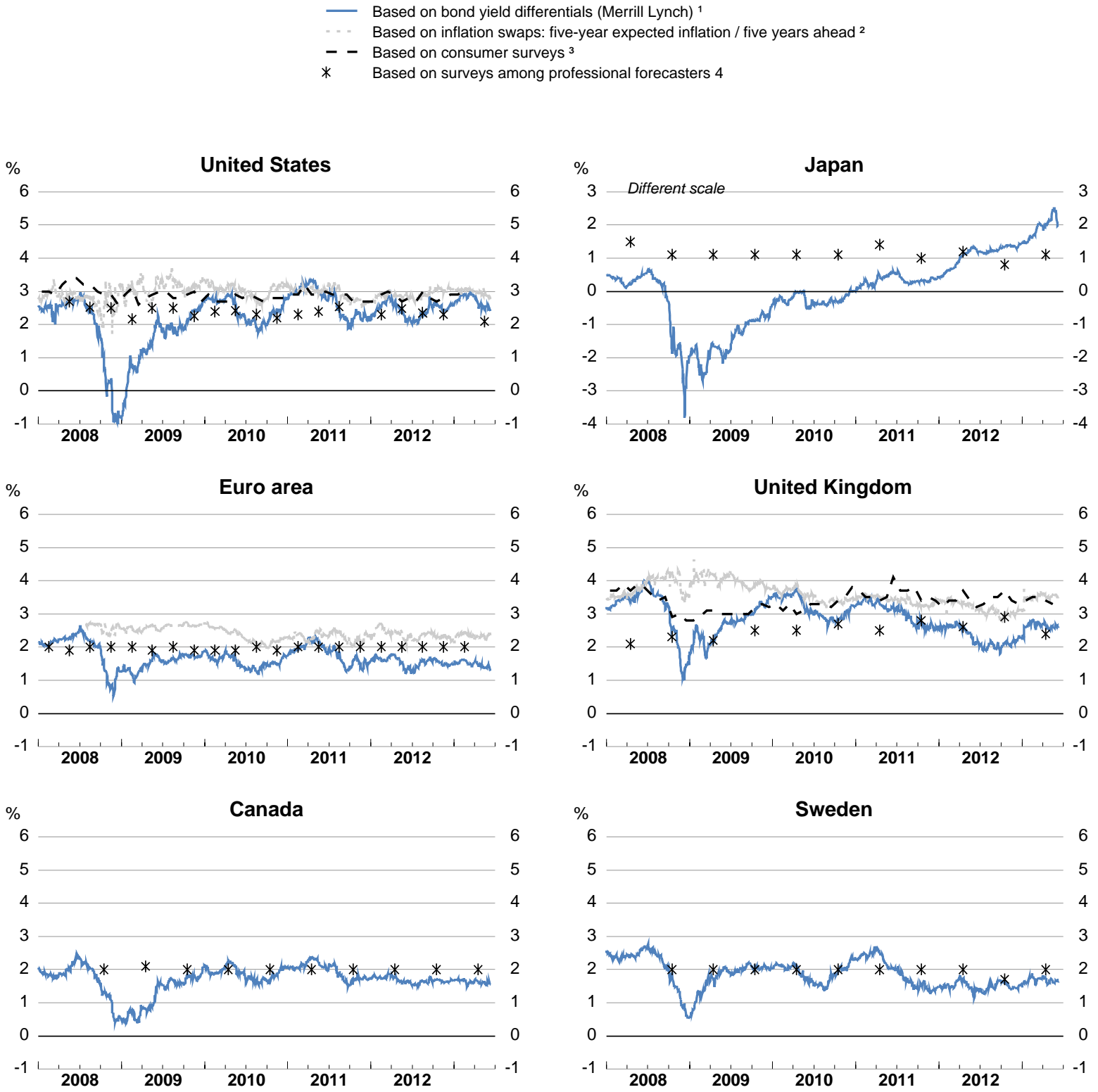

1. Expected inflation implied by the yield differential between 10-year government benchmark bonds and inflation-indexed bonds.

2. Expected average annual inflation 5 to 10 years ahead, based on 5 -year and 10 -year inflation swaps. An inflation swap is a contract where one party pays a fixed rate and the other one pays actual inflation.

3. Expected inflation over the next 5 to 10 years. Based on the Reuters/University of Michigan Surveys of Consumers for the United States, and on Citigroup/YouGov survey for the United Kingdom.

4. Expected average rate of CPI inflation over the next 10 years for the United States, based on the Survey of Professional Forecasters (SPF) by the Federal Reserve Bank of Philadelphia. Expected HICP inflation rate 5 year ahead for the euro area, based on the SPF by the ECB. Expected average rate of CPI inflation 6 to 10 years ahead for Japan, the United Kingdom, Canada and Sweden, based on Consensus Forecasts.

Source: Datastream, Bloomberg, University of Michigan Survey of Consumers, Citigroup, Consensus Forecasts, Federal Reserve Bank of Philadelphia, ECB. 
Figure 12. Non-performing loans

Share of total loans (different scales)
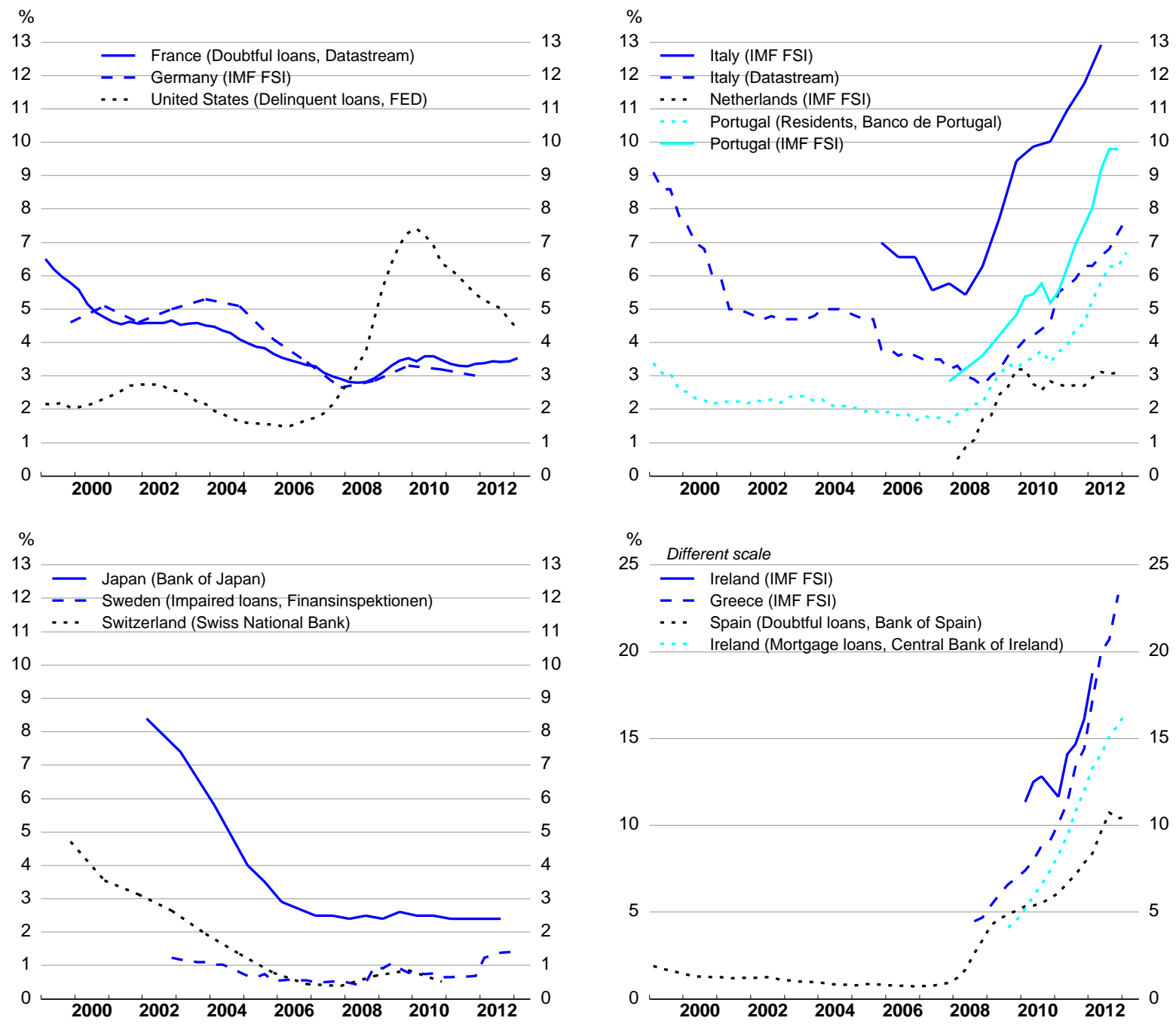

Note: A loan is non-performing when payments of interest and principal are past due by 90 days or more, or at least 90 days of interest payments have been capitalised, refinanced or delayed by an agreement, or payments are less than 90 days overdue, but there are other good reasons to doubt that payments will be made in full. Impaired/delinquent/doubtful loans refer to the situation when it is probable that the all or part of payments will not be received. For the United States, delinquent loans and leases are those past due 30 days or more and still accruing interest as well as those in nonaccrual status.

Source: IMF Financial Soundness Indicators (FSI), Datastream and national central banks. 


\section{Figure 13. Bank loan-loss provisions}

Per cent of total assets
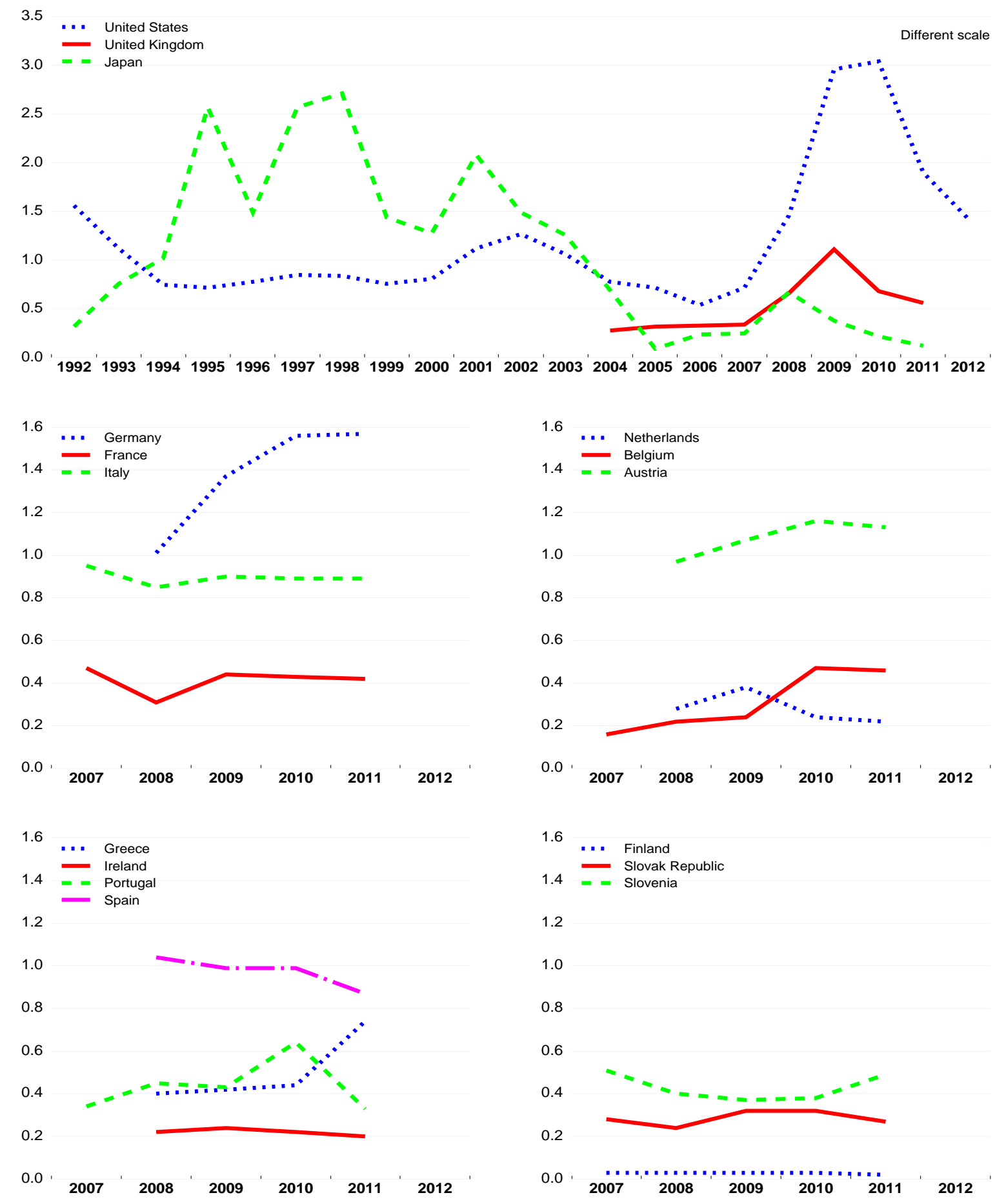

Source: ECB, Federal Deposit Insurance Corporation, Bank of England and Financial Services Agency. 


\section{Figure 14. Banks' market-to-book ratios}

Last observation: 2013Q1

United States
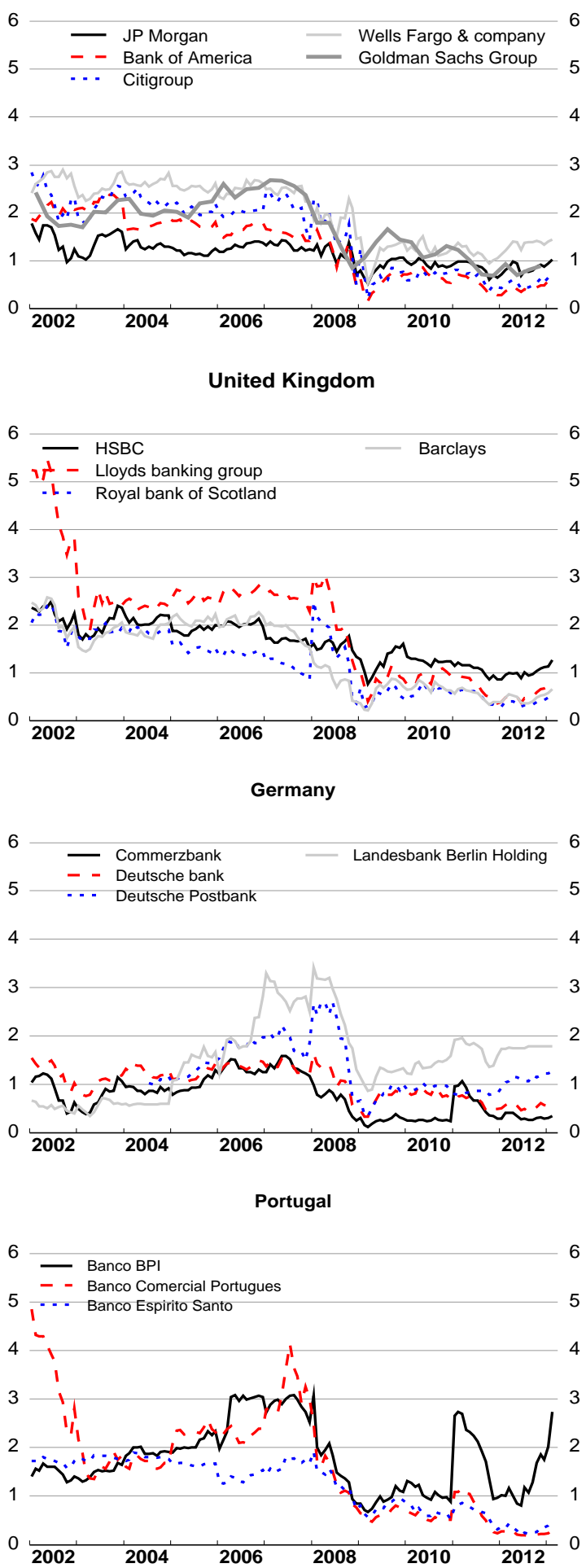

Japan

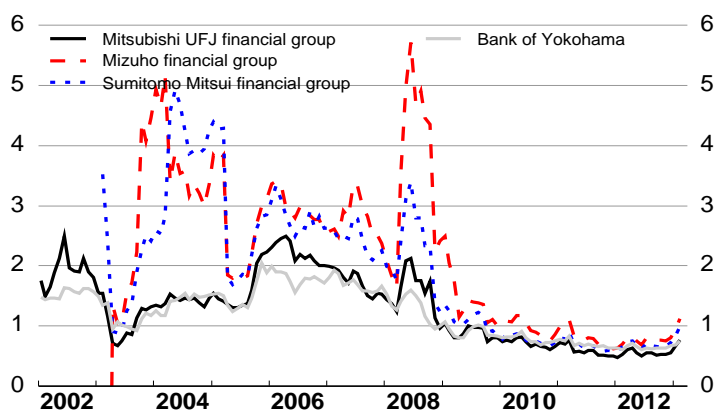

France

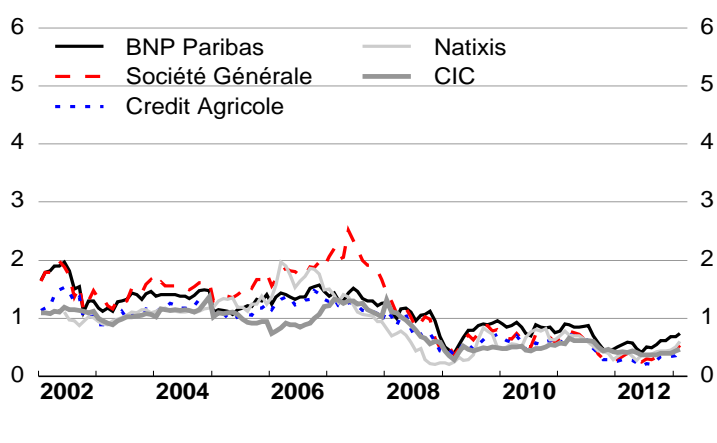

Italy
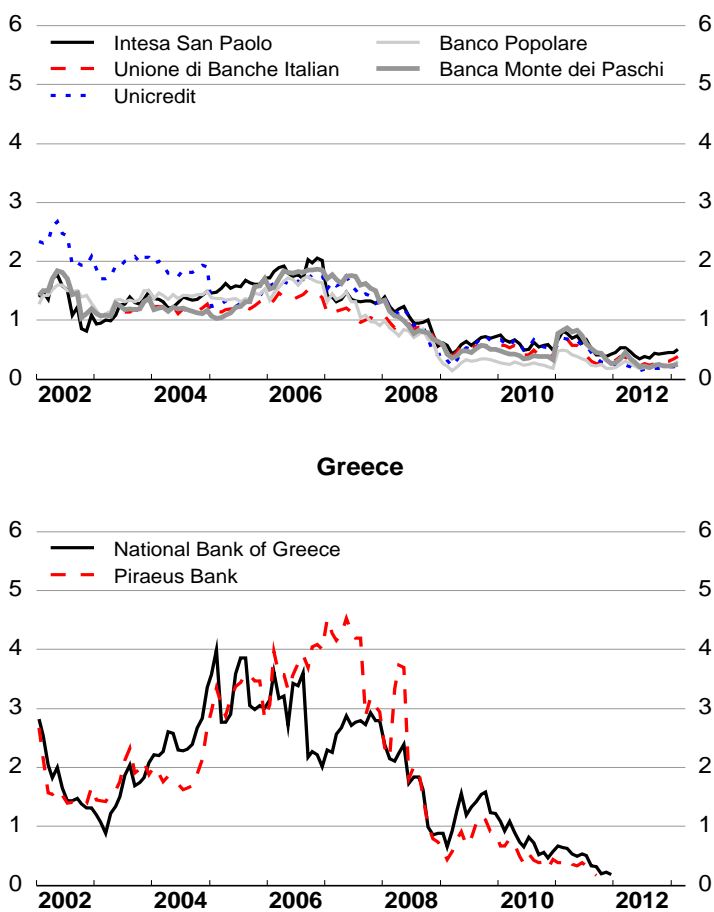

Source: Bloomberg and Datastream. 


\section{Figure 15. Enterprise bankruptcies}

Number of bankruptcies, Index $2006=100^{1}$
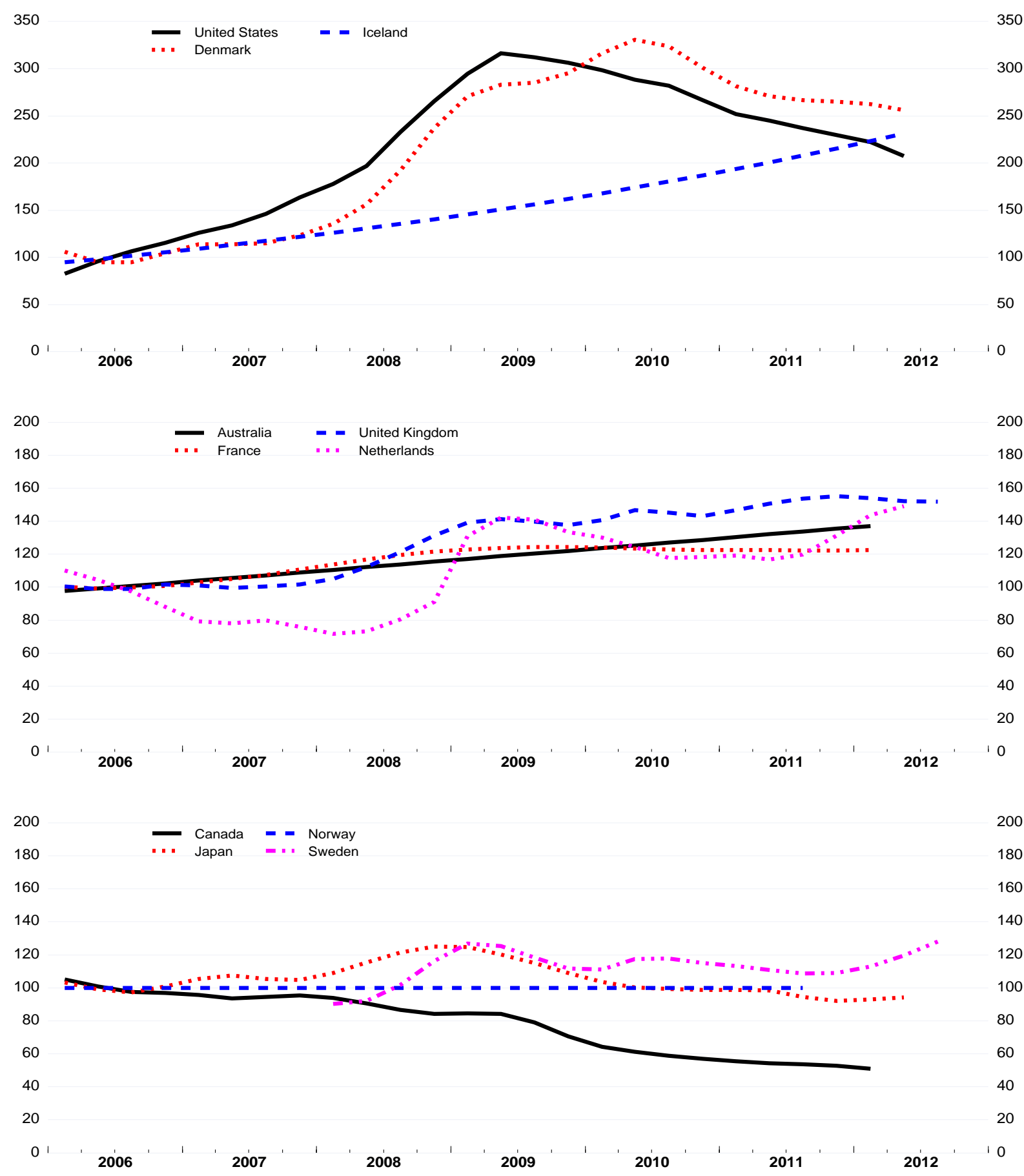

Note: Bankruptcy is used as an indicator for enterprises death. The concept differs across countries - see OECD (2012) Entrepreneurship at a Glance 2012 (pp. 16-17).

1. Except for Sweden, Index $2008=100$.

Source: OECD Timely Indicators of Entrepreneurship Database. 
Figure 16. Real GDP and labour productivity in past recessions

Index (indicated quarter $=100$ )

United States - Real GDP

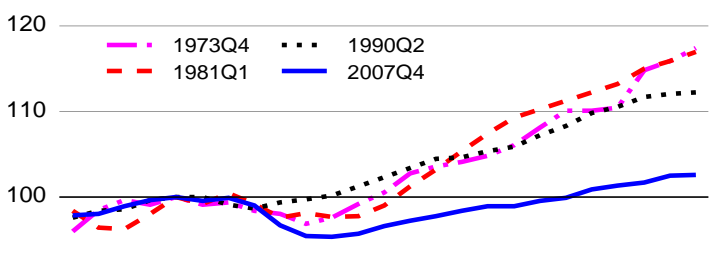

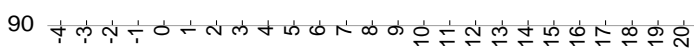

Japan - Real GDP

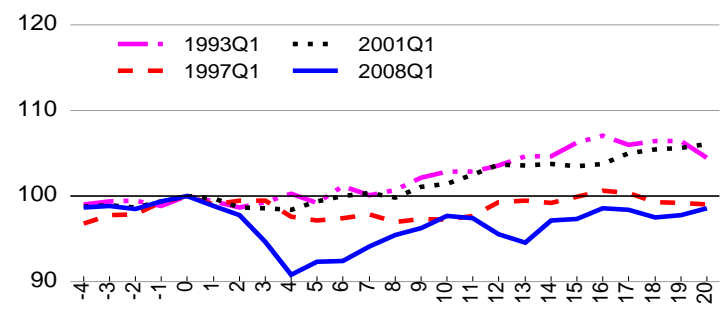

United Kingdom - Real GDP

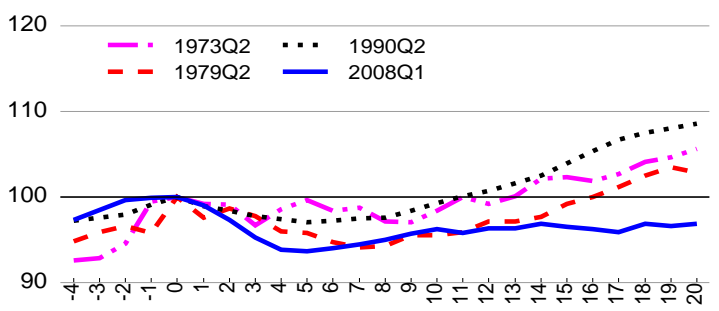

Germany - Real GDP

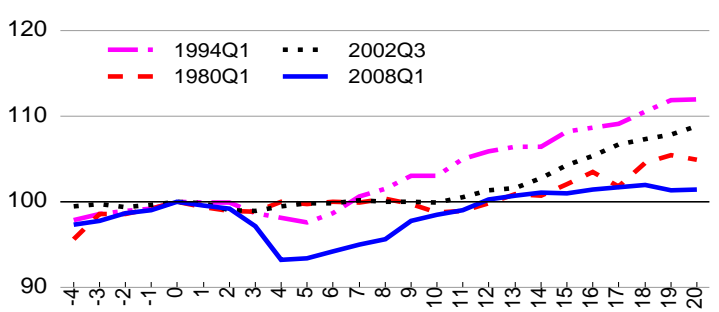

United States - Real GDP

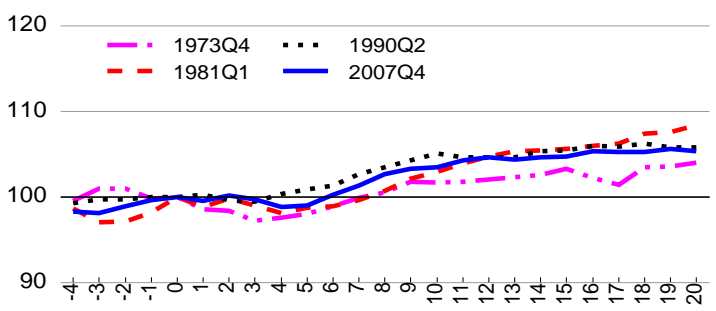

Japan - Labour productivity

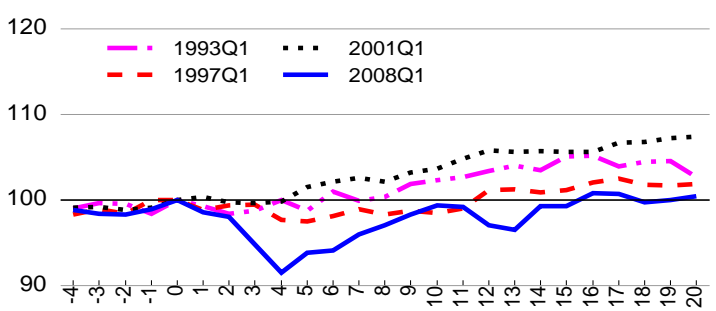

United Kingdom - Labour productivity

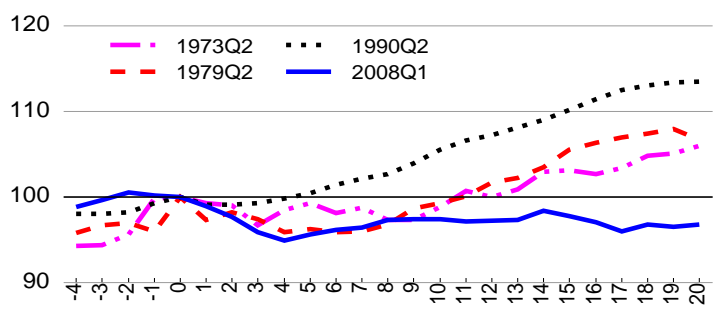

Germany - Labour productivity

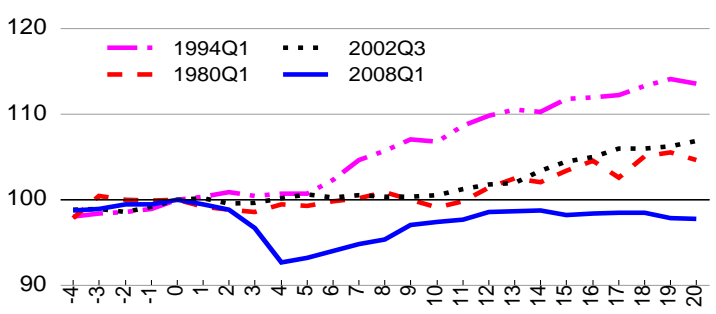

Note: Dates refer to pre-recession peaks on real GDP. Labour productivity is the ratio of GDP to total employment. Horizontal axes show number of quarters before and after the GDP peak.

Source: OECD, Economic Outlook 93 Database. 
Figure 17. Labour productivity since the Great Recession

Index $(2008 Q 1=100)($ Last observation: 2013Q2)
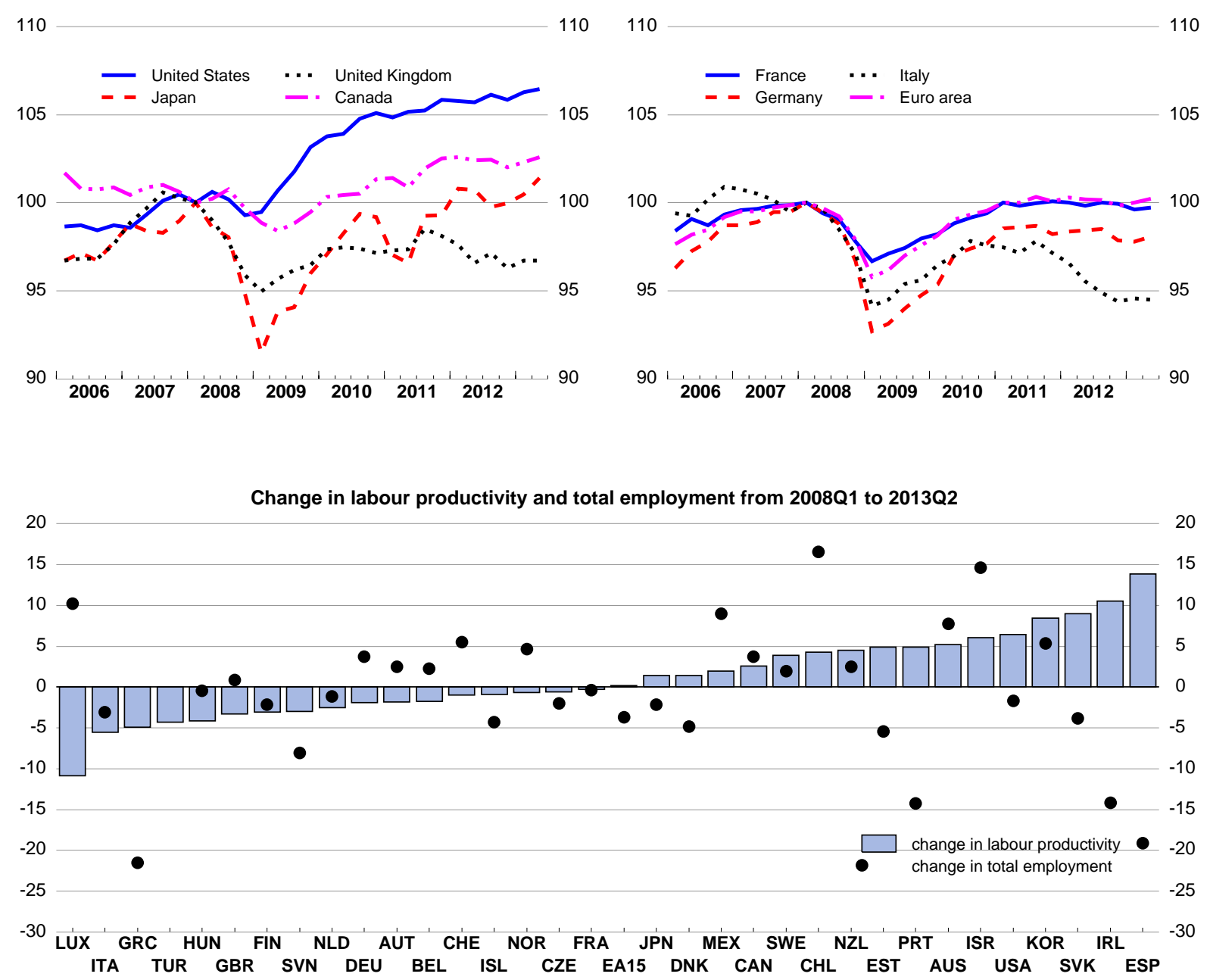

Note: Labour productivity is the ratio of GDP to total employment.

Source: OECD Economic Outlook 93 database. 
Figure 18. Nominal effective exchange rates since the onset of the Great Recession

Nominal effective exchange rates (January $2007=100)$ (Last observation: May 2013)

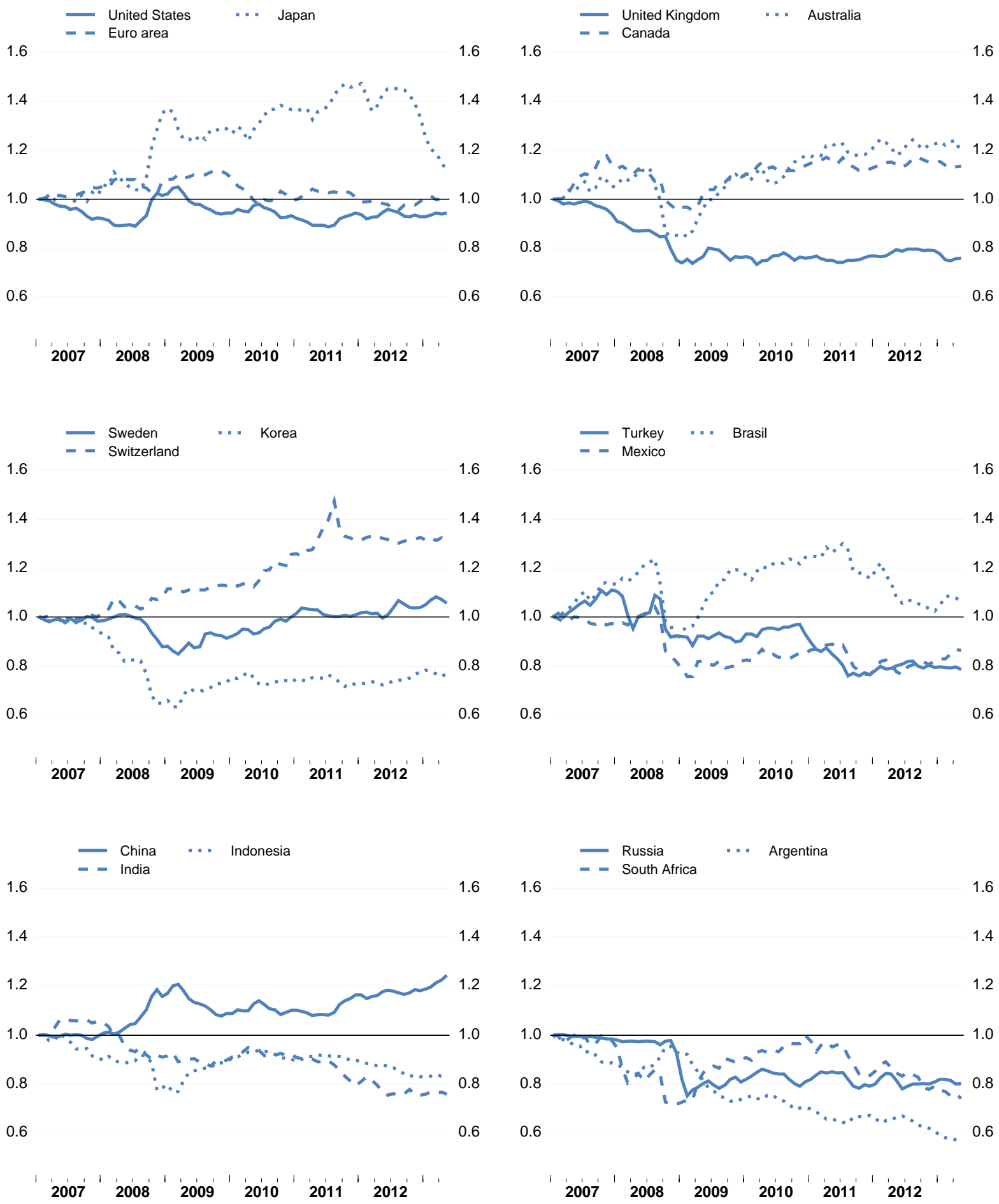

Source: OECD Economic Outlook 93 database. 
$\mathrm{ECO} / \mathrm{WKP}(2013) 74$

\section{WORKING PAPERS}

The full series of Economics Department Working Papers can be consulted at www.oecd.org/eco/workingpapers/

1081. The effectiveness of monetary policy since the onset of the financial crisis

(August 2013) by Romain Bouis, Łukasz Rawdanowicz, Jean-Paul Renne, Shingo Watanabe and Ane Kathrine Christensen

1080. Responding to key well-being challenges in Austria

(August 2013) by Rauf Gönenç, Oliver Röhn, Christian Beer and Andreas Wörgötter

1079. Austria's well-being goes beyond GDP

(August 2013) by Oliver Röhn, Rauf Gönenç, Christian Beer and Romina Boarini

1078. Improving fiscal federal relations for a stronger Mexico

(August 2013) by Aida Caldera Sánchez

1077. Deleveraging: challenges, progress and policies

(August 2013) by Romain Bouis, Ane Kathrine Christensen and Boris Cournède

1076. Policies to support sustainable long-term growth in New Zealand

(July 2013) by Calista Cheung

1075. Do structural policies affect macroeconomic stability?

(July 2013) by Volker Ziemann

1074. A simple fiscal stress testing model - case studies of Austrian, Czech and German economies (July 2013) by Ondra Kamenik, Zdenek Tuma, David Vavra and Zuzana Smidova

1073. Road connectivity and the border effect: evidence from Europe

(July 2013) by Henrik Braconier and Mauro Pisu

1072. Fiscal consolidation across government levels. Part 3: Intergovernmental grants, pro- or counter-cyclical?

(July 2013) by Hansjörg Blöchliger and Balázs Égert

1071. Fiscal consolidation across government levels. Part 2: Fiscal rules for sub-central governments, update of the institutional indicator

(July 2013) by Kaja Fredriksen

1070. Fiscal consolidation across government levels. Part 1: How much, what policies?

(July 2013) by Hansjörg Blöchliger

1069. Restructuring the electricity sector and promoting green growth in Japan

(June 2013) by Randall S. Jones and Myungkyoo Kim

1068. Labour market policies to promote growth and social cohesion in Korea

(June 2013) by Randall S. Jones and Satoshi Urasawa

1067. Education reform in Korea

(June 2013) by Randall S. Jones 
1066. Belgium: enhancing the cost efficiency and flexibility of the health sector to adjust to population ageing

(June 2013) by Stéphane Sorbe

1065. Italy and the euro area crisis: securing fiscal sustainability and financial stability (June 2013) by Oliver Denk

1064. Policy implementation in Italy: legislation, public administration and the rule of law (June 2013) by Paul O’Brien

1063. Greening growth in Luxembourg

(June 2013) by Nicola Brandt

Vers une croissance plus verte en Luxembourg

(juin 2013) par Nicola Brandt

1062. The post-crisis narrowing of international imbalances - cyclical or durable?

(June 2013) by Patrice Ollivaud and Cyrille Schwellnus

1061. Restructuring welfare spending in Slovenia

(June 2013) by Rafał Kierzenkowski

1060. The economics of civil justice: new cross-country data and empirics

by G. Palumbo; G. Giupponi; L. Nunziata and J. Mora-Sanguinetti (forthcoming)

1059. Banks' restructuring and smooth deleveraging of the private sector in Slovenia

(June 2013) by Olena Havrylchyk

1058. Assessing the efficiency of welfare spending in Slovenia with data envelopment analysis

(June 2013) by Matevz Hribernik and Rafał Kierzenkowski

1057. Policy determinants of school outcomes under model uncertainty: evidence from South Africa (June 2013) by Thomas Laurent, Fabrice Murtin, Geoff Barnard, Dean Janse van Rensburg, Vijay Reddy, George Frempong and Lolita Winnaar

1056. Improving education quality in South Africa

(June 2013) by Fabrice Murtin

1055. The 90\% public debt threshold: the rise and fall of a stylised fact

(June 2013) by Balázs Égert

1054. Challenges to sustain Poland's growth model

(June 2013) by Balázs Égert and Rafał Kierzenkowski

1053. Reforming agriculture and promoting Japan's integration in the world economy (May 2013) by Randall S. Jones and Shingo Kimura

1052. Inequality and poverty in the United States: public policies for inclusive growth (May 2013) by Oliver Denk, Robert Hagemann, Patrick Lenain and Valentin Somma 